\title{
The Maoris of New Zealand
}

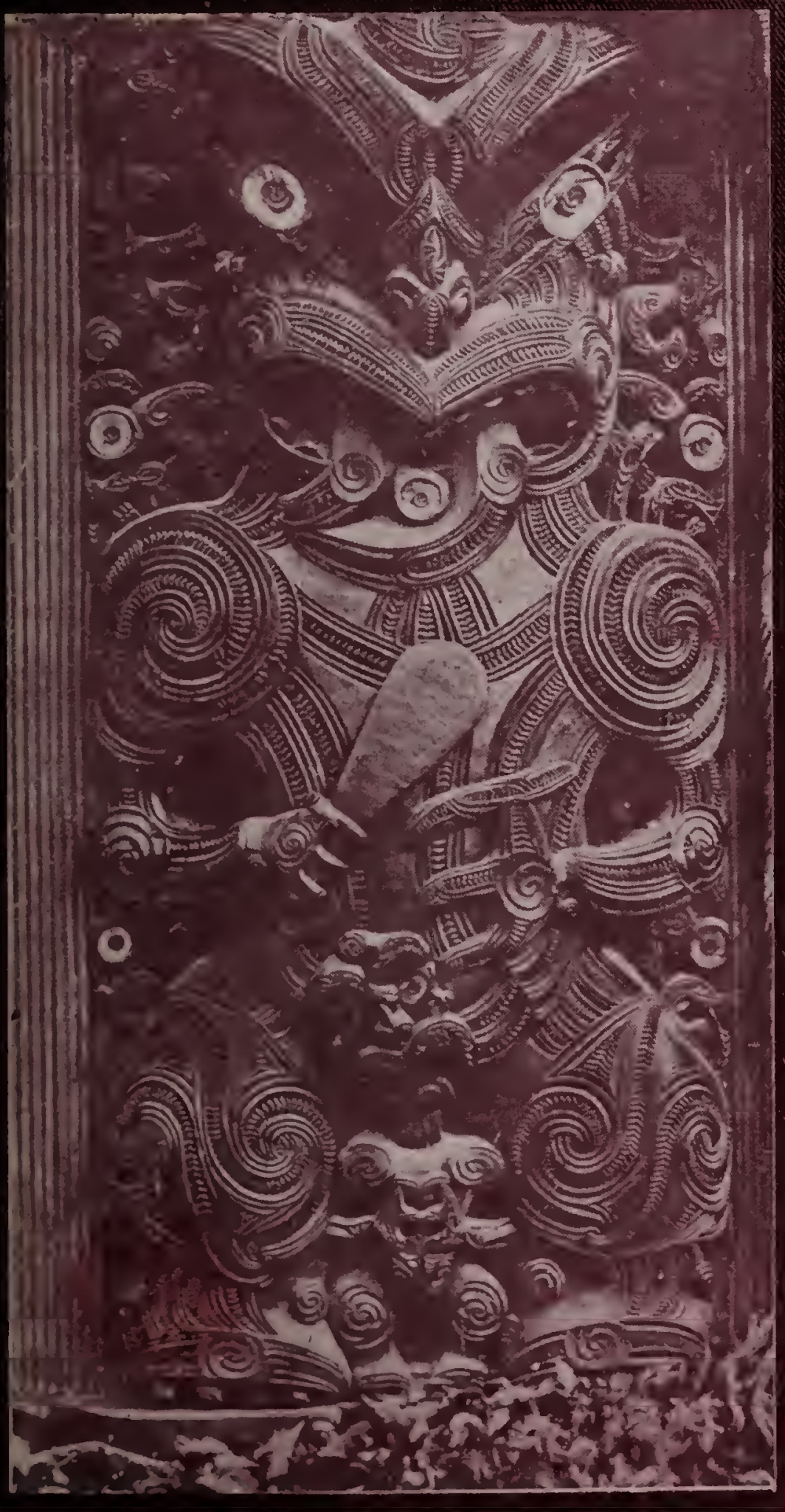

D. V. LUCAS 


\section{$\operatorname{Re} 120,818$}

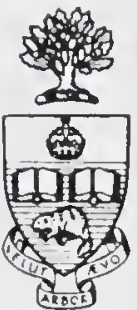

Library

of the

University of Toronto 

Digitized by the Internet Archive in 2019 with funding from University of Toronto 

THE MAORIS OF NEW ZEALAND 



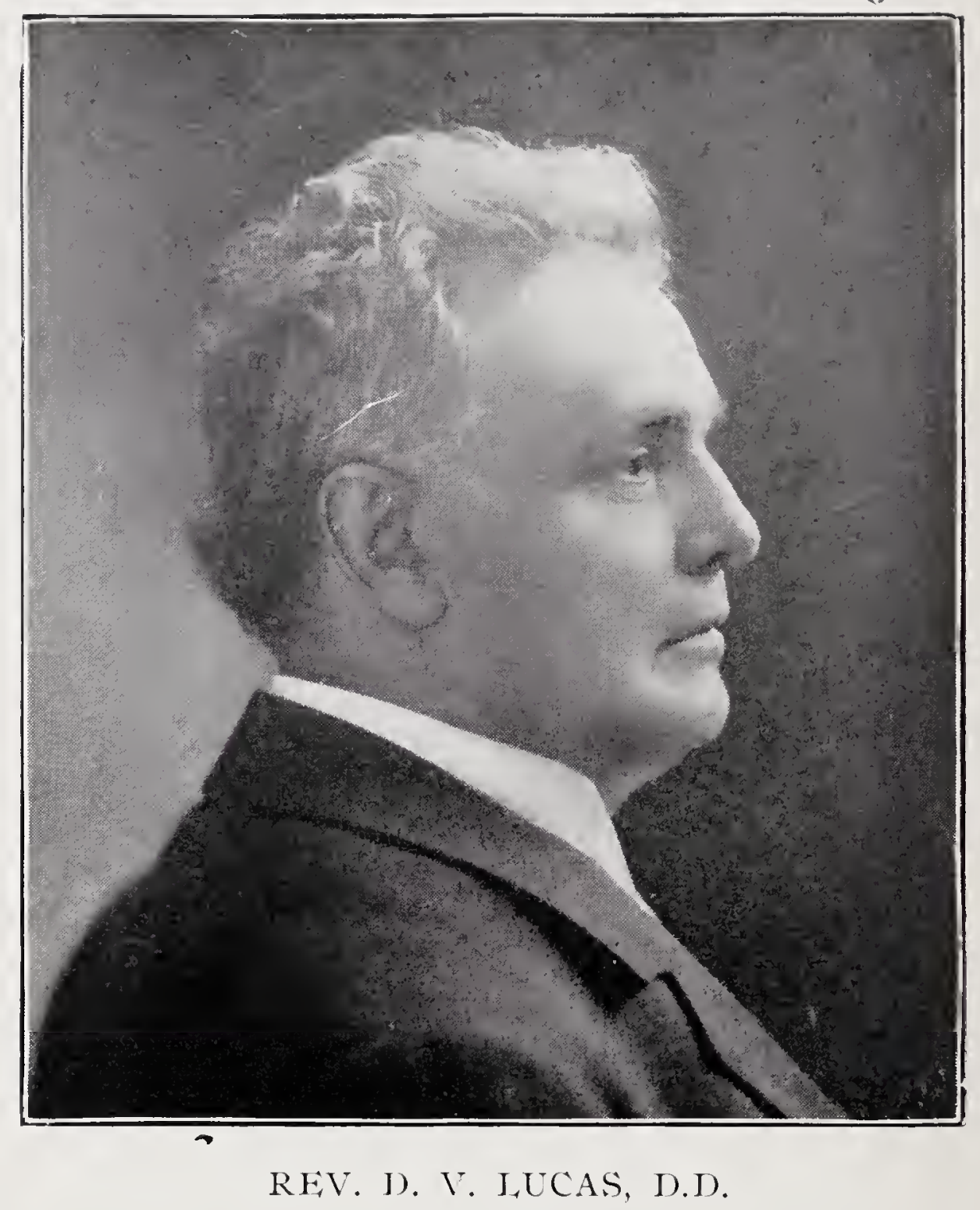




\title{
THE MAORIS OF
} NEW ZEALAND

\author{
By \\ REV. D. V. LUCAS, D.D.
}

Author of "Railway Sermons," "All About Canada."

"Australia and Homeward." "Canaan and Canada."

"Federation of the British Empire." etc., etc.

TORONTO

WILLIAM BRIGGS

1910 
Copyright, Canada, 1910, by D. V. LUCAS. 


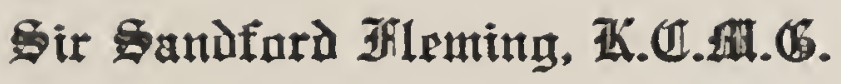

In remembrance of many years of the warmest and sincerest friendship

this volume is respectfully

dedicated. 



\section{INTRODUCTION}

IT is but right to say to the reader that I spent a year in New Zealand, visiting almost all parts of the two main islands, each nearly five hundred miles in length, and had abundant opportunity, therefore, of observing the native people of whom I write, preaching to hundreds of them, visiting them in their villages (pahs) and conversing with them.

I had the good fortune also to meet and converse with Sir George Gray, who always, to very old age, took a deep interest in them and mastered their language, and am very largely indebted to Sir George for the information given the reader respecting their poetry and folk-lore.

The whole of Sir George's works on the Maoris are in my possession, as also fire volumes of Mr. John White's complete works on the same subject in both languages. Unfortunately Mr. White's fifth volume was burned in a conflagration which consumed the Parliament Buildings and all their contents. My volumes, therefore, are I., II., III., IV. and VI. Fortunately other writers are able to contribute sufficient matter to almost cover the loss. I say "almost," for Mr. White was the most prolific writer of all who have written upon this subject.

I sincerely hope that some young native New Zealander 


\section{INTRODUCTION.}

will take up the subject and give the world a work worthy of his clever ancestors. For they are ancestors of whom no man need be ashamed.

I hope, too, that none of his people or any other will ever "take his stand on a broken arch of London Bridge to sketch the ruins of St. Paul's."

It was my good fortune also to meet several of these Maori M.P.'s in the New Zealand Parliament in much less than a century after their fathers had been cannibals.

Surely the world is rapidly progressing. May our God lift up all the nations. He expects much from us who have been born into the world in the midst of clearer light.

D. V. LUCAS.

St. Catharines, April, 1910. 


\section{CONTENTS}

Maoris of New Zealand -
Their Poets and Musicians





\section{ILLUSTRATIONS}

\section{8}

PATF

Rev. D. V. Lucas, D.D. - $\quad$ - $\quad$ - $\quad$ - $\quad$ Frontispiece

Paroto, an M.P. - $\quad$ - $\quad$ - $\quad$ - $\quad$ - $\quad$ - $\quad$ - $\quad$ - $\quad$ - 16

A Great Chief and Warrior - $\quad$ - $\quad$ - $\quad$ - 20

Huia (Hoo-yeh) - $\quad$ - $\quad$ - $\quad$ - $\quad$ - $\quad$ - $\quad$ - $\quad$ - $\quad 22$

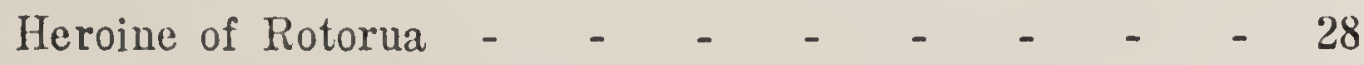

Great Chief (Ta-whee-0) - $\quad$ - $\quad$ - $\quad$ - $\quad$ - $\quad$ - 42

Pare Whabreranqonna

Mare Pa-0-re

A Dwelling - $\quad$ - $\quad$ - $\quad$ - $\quad$ - $\quad$ - $\quad$ - $\quad$ - 56

Entrance to a Cemetery - $\quad$ - $\quad$ - $\quad$ - $\quad$ - $\quad$ - $\quad$ - 84

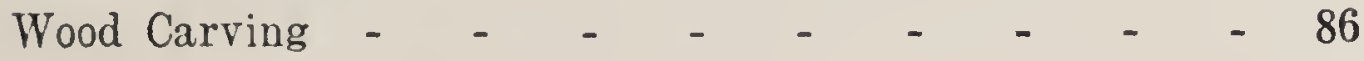

Wood Carving - $\quad$ - $\quad$ - $\quad$ - $\quad$ - $\quad$ - $\quad$ - $\quad 118$

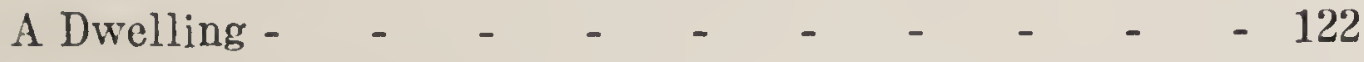

Moetara - $\quad$ - $\quad$ - $\quad$ - $\quad$ - $\quad$ - $\quad$ - $\quad$ - $\quad$ - 126 

THE MAORIS OF NEW ZEALAND 



\section{Maoris* of New Zealand}

THIS book tells its readers of cannibals who, contrary to all our knowledge or imaginings of cannibals, were highly intelligent, conscientiously moral, artistic, eloquent, poetic and musical.

Can we truthfully call such people savages? Yet this has been our describing designation of those who eat human flesh.

The fact is, these aborigines of New Zealand seem to have been an exception to all aboriginal races with which the English have come in contact.

Considering their numbers, which were small compared with continental races, they offered the strongest and best. ordered resistance to British forces which Britons ever met. However, no matter how well equipped with their native weapons, clubs and spears cannot hold out long against disciplined soldiers armed with guns and heavier ordnance.

Do you think it cruel and wicked for civilized men to

* Pronounced Mow-ries. 


\section{MAORIS OF NEW ZEALAND}

visit these native people and destroy them by the hundred or the thousand because they are provided with superior weapons, when perhaps they would hardly have the courage to attempt such a task if no better equipped than they?

In the native New Zealander you have a man who appreciates nothing, in a supposed enemy, except brute force. If he has to submit to it, when he has done his best, he does so with a good grace, as he has done in this instance, and respects it, because he discovers a power superior to his own.

Their subjugation to civilized power has resulted in a complete cessation of those tribal wars which were continuous, and in which thousands were slain-many more thousands than those who fell in their resistance to their conquerors. Now they have peace among themselves as well as between them and their victors.

The English gave them a written language, which they had not until they were conquered.

When Sir George Gray, for a time Governor of the islands, and Mr. John White and others went among them, and by great kindness and unlimited sympathy made the natives feel that they were real friends, they found, among many other interesting things, that for a long time these people had schools which were open through four months of 


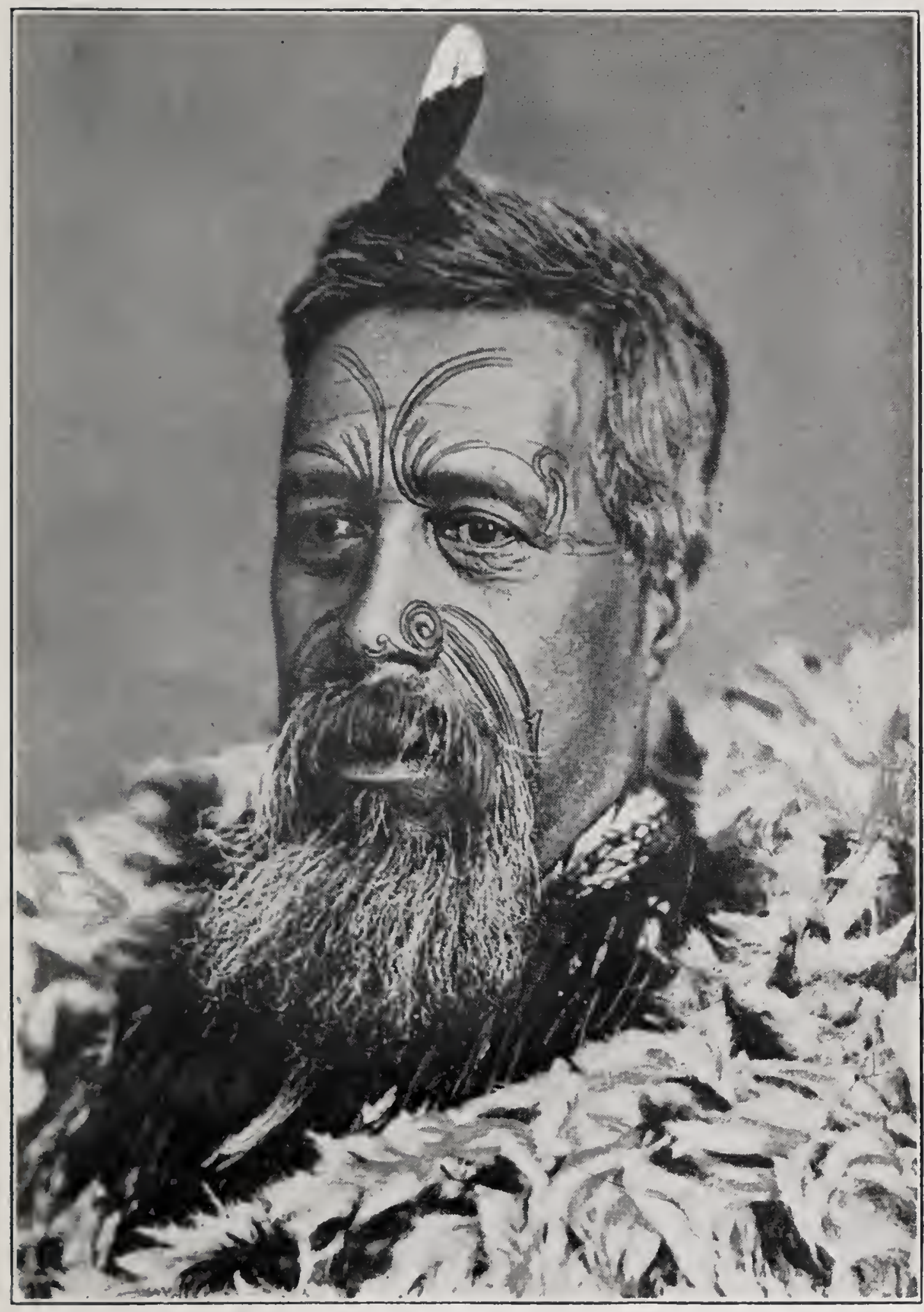

I'A RO'O

A vember of the rew Zealand Parliament. 



\section{MAORIS OF NEW ZEALAND}

each year, to which especially the sons of priests and chiefs had to go, there to commit to memory histories of their wars, their traditions, songs and folklore.

Then, by means of the written language, they have given to the world the wonderful history and aboriginal conditions of these very remarkable people.

As to their origin, I think there is some ground for believing that their ancestors came to New Zealand from the Sandwich Islands.

From whence the natives of the Sandwich Islands came, it is hard to trace.

The people of those islands deny that their fathers were ever cannibals.

It is very interesting to discover that among the people of the entire Hawaiian group there was a general knowledge of those things believed and taught by the Hebrews.

For instance, Captain Cook found during his short stay among them that the system of refuge cities for the protection of the unintentional homicide was almost, if not fully, identical with that established by Moses and Joshua.

Their ideas respecting the flood tallied well with that given us in the Pentateuch, and what makes the fact more striking is that the name among them of the Deliverer who saved a few of his race by his big canoe was Nui (Noah). 
However, our book deals with the New Zealand people, and not with the Hawaiians, though there is reasonable evidence that the former came originally from the more northern group of islands.

If it may be conceived that they are descendants of the Inst ten tribes of Israel, while it will ever be a puzzle to discover how their fathers reached these islands, that supposition will explain why there are abundant evidences of an earlier civilization of no low degree.

It is thought by some that it is not very long since New Zealand and the continent of Asia were connected by dry land. The existence of the moa and other wingless and flightless birds would seem to confirm that idea. These immense birds, unable to either fly or swim, must have come upon dry land to this southernmost extremity of the Asiatic continent and had there made their habitat prior to the sinking down of the link of land between them and the larger portion of Asia. Ignoring the claim of those who argue that the New Zealander came from Hawaii, he may have found his way to his present home precisely as the birds and four-footed animals did.

Though their ideas of the flood and of cities of refuge and other points of resemblance to Hebrew History may not be so definite and circumstantial as those of the Sand- 
wich Islanders, yet they have well-established ideas, commonly held among them, of the creation of the world and of the redemption of the world after man had become corrupt through transgression, as I will show from some of their poetic effusions.

For there were poets among them who, as the reader will, I think, readily acknowledge, deserve to rank among classical poets of Greece and Rome.

Though dark of skin, as a look at the pictures of a few of them, inserted for the purpose of giving the reader a fuller knowledge of them, will show, the picture reveals at once that they are very far removed from the African. Notice the hair, the forehead, the nose. While these facial features take him as far away from the negro as the east is from the west, the eye tells us that he is not a truly Asiatic or Mongolian.

From whence, then, came he? Let that pass. I do not know. We will deal with him as we find him.

While holding uniformly very fixed views respecting the creation of the worlds and the separation of cosmos from chaos, they had a very strong prejudice towards what they regarded as orthodoxy.

They held that a god, "Tiki" (te-ke), had made man. They could not excuse any departure from that belief. 


\section{MAORIS OF NEW ZEALAND}

However, one priest did depart from the true faith as to this very essential doctrine.

An old warrior, "Tewera," extremely orthodox, was very much offended. The more he thought of it the more wrathy he became because of the false teaching of the erratic priest.

When war happened the priests were obliged to take their place in the ranks and fight like other folks. This erring priest was killed. Old Tewera got clay and stuffed it into his mouth and his ears, that no heresy could possibly escape. Then he made an oven of the proper size for a priest, and, after heating it, into it he thrust the body of the heretic and roasted him thoroughly, and kept right on, except at spells to let his dinner settle, until he ate the heretic entirely up and scraped his bones, remarking with much satisfaction that we would have no more of his unorthodox lies.

O you preachers, a little loose in your theology, I pray you keep away from New Zealand, for if old Tewera is not now alive, some of his descendants may be, and it may not go well with you.

Heretics, so called, at least, have been roasted often, but the cannibal seemed to think that the work was not well done till the heretic was eaten. 


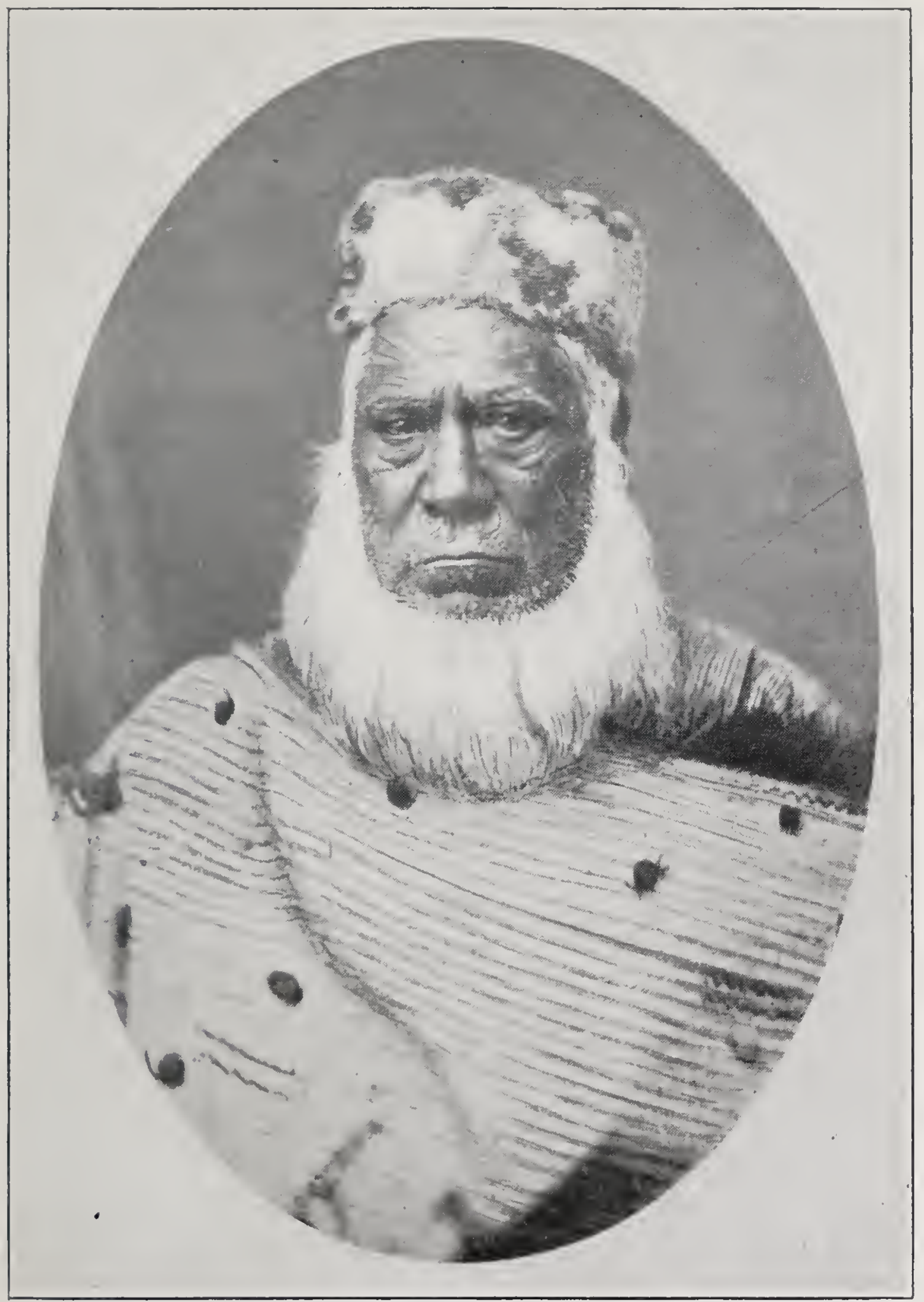

A GREAT CHIEF AND WARRIOR 



\section{MAORIS OF NEW ZEALAND}

It does not seem that their cannibalism went further, as \&. rule, than eating their enemies slain in battle.

Sometimes a successful warrior would preserve the head of an enemy, especially if well tattooed, and keep it on a shelf in his house, and now and then take it down and talk to it after this fashion: "So you thought you would run away from me, did you? Yes, but my spear was too quick for you; it caught up to you. Where is your brother? Killed and roasted to make food for my stomach. Where is your wife? There she sits; mine now. Where are your sons? There they are, carrying burdens for me; my slaves."

You will notice that the head in each picture of a Maori, male or female, is ornamented by a feather with a white tip. These ornamental feathers are to the Maori what the eagle feathers are to the North American Indian. He could hardly think himself respectably dressed if not adorned with one or more of these tail-feathers of the huia (hoo-yeh). The bird is about the size of a pigeon. The male and female are exactly alike in shape, size and color, almost a blue black, the tail-feathers being tipped with white for about one inch back from the points. The only difference in the form of the sexes is, the male has a wedgeshaped beak, somewhat like that of the crow, though a 


\section{MAORIS OF NEW ZEALAND}

little shorter and broader at the base. The female has a long, bent beak, the size of a lady's crochet needle, quite three times as long as that of the male. Without the stronger, wedge-shaped beak, the male could not peck through the rough, hard bark of the tree where he hears a large white grub gnawing. The grub, disturbed by the pecking, draws away from it as far as he can, so that the bird with his thick beak cannot reach him when the bark is pecked through. He whistles for his mate, who runs her long, thin, curved beak into the hole until she reaches the grub, and, having pulled him out, a dividend is declared.

For some years it was thought by the white people that the long-beaked bird was the male, because it seemed to be feeding the other.

It is a standing joke in New Zealand that the bill of the female is always the longest.

This queer provision of nature to provide for the wants of this bird gives it a notoriety and popularity which is appreciated by the natives, who regard the tail-feathers of the huia as of great value, especially as the bird is not very common. In fact, it is very difficult to obtain now.

The other queer-looking, twisted-up ornament hanging around the neck of one of the young women is a token indicating that she is of royal blood, her father being either 


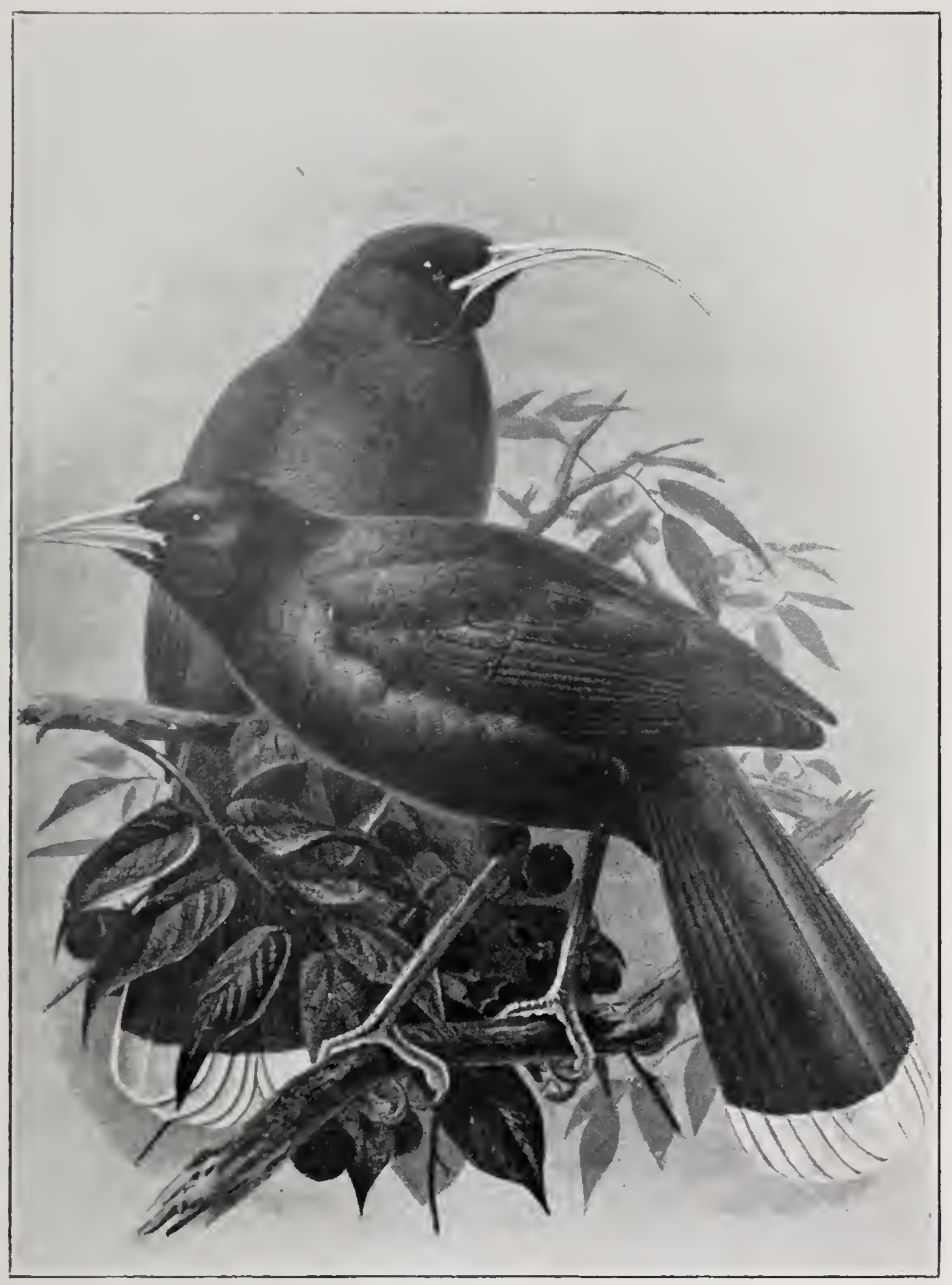

HLIA (HOO-YTH) 



\section{MAORIS OF NEW ZEALAND}

a very great chief or a king. She would not dare to wear it if she could not establish her right to do so.

All things belonging to a chief or great warrior or king are taboo to the common people. To handle his spear or war-club, or to put on a coat of his, or his mat over your shoulders, is grossly to insult his highness, and revenge must ensue. The insulted one is so enraged that he has not always time to hunt up the wrong-doer. Anyone near to him will do just as well. A slave or a brother or parent is attacked and slain.

Some one near of kin, not knowing how the trouble originated, must seek revenge by retaliation. He perhaps slays two. Then the feud begins to make headway.

Quarrels of this kind, and with no larger origin, used to run on for years, till hundreds or sometimes thousands were slain.

The worst wars were those which occurred between the inhabitants of the two main islands. New Zealand consists principally of two islands, each about five hundred miles long, separated by about twenty miles of water called Cook's Straits. The Maoris of the lower or southernmost island were the more aggressive of the two, and wars of the severest kind were fought in the northern island, those from the south having crossed the straits and attacked the 


\section{MAORIS OF NEW ZEALAND}

northern tribes for some trivial reason, or often for no reason at all, save that the fighting spirit was in them and could not be gratified without the shedding of blood. They were fierce fighters, and their conflicts were no child's play.

\section{Their Poets and Musicians.}

That they should have had warriors, and sometimes very eloquent warriors, does not surprise us, for all who are at all familiar with the conditions of aboriginal peoples are aware of the existence of such among them, even where there was no written language, or no means of intellectual education: but that they should have had poets worthy of being classed with some of the classical poets of ancient times, and while they were yet cannibals, is almost beyond our belief, and would be wholly so if our faith were not supported by the most reliable testimony.

The reading world will always be indebted to Sir George Gray, Mr. John White, and a few others not so well known, for going among them, mastering their tongue and making themselves thoroughly familiar with their folklore and their ancient customs.

Their poets, in their natural imagery, allowed their thoughts to move so rapidly that they could not attend very largely to detail. The natural simile was seized upon 


\section{MAORIS OF NEW ZEALAND}

or alluded to at one or two striking points only, and these of the most lively phases. The setting sun, the red evening sky, the twinkling of a star, the rising moon or breaking dawn, the flash of the lightning or the rolling thunder, the hooting of an owl or the roaring of the sea -almost all phenomena of nature were woven into their songs.

Their poetry may be classified as lyrical, historical and ceremonial. Their lyrical poetry contains martial, vengeful, taunting, humorous and exciting songs. Their historic songs embraced, for the greater part, the warlike deeds of their ancestors. These they also recited in traditions and legends. The ceremonial poetry was chanted for the purpose of securing the aid of or dispelling spiritual influences, sometimes containing a command or threat.

The following song seems to have been intended to allure an enemy into battle, by some small degree of flattery, that he might be slain and eaten.

Oh! spirit of the light
Of day, a halo on
Thy head is seen.
Lift up thy head,
Lift it up on high,
Lift it o'er the hills,
See there thy host
Upon the ocean shore. 
Go there my foe, in

Light of day, and

Pass the god of war.

'Tis there the battle

Rages. There sleeps not,

The enemy of peace.

Nay, 'tis war in battle

Fierce, as when a

Northern cloud let

Loose and drifting on

In blackness bursting,

Drowns the shrieks of

Lips that utter grief.

But you say, the

Feathers lift you,

And you fly from

Me, and death, with

Power supreme of life.

But no, my glow of life

Is still a power

And can with ease

Convey me to the north.

There shall thy cry

Be heard, thy shrieking call

Re-echo to the heavens,

And to the highest peak

My voice in startled

Accents will call in vain.

"Go, climb the mountains, Assisted by the roots of Trees, where we wage 


\section{MAORIS OF NEW ZEALAND}

Our war in presence

Of thy gods.

There thou shalt be,

As shark with broken fin.

"There thou wilt start,

And be as food

Offered to the gods

On sacred pile.

What are the mountains

Which I yonder see,

The Whata and Rangota?

"There let us wage

Our war. The comet

Gives the sign.

My slashing weapon

Beaten on the skull

Shall give thy head

To me for food.

Ah! Sweet food."

A shorter poem tells of the misery occasioned by famine, resulting from drought, although these poor people attributed all such calamities to the anger of the gods.

Welcome, Rupé, yet

Wait awhile with me,

And I will tell

Thee what the ancients

Say of smiles or frowns

The seasons give. 
Two years of food deficient, Then two years of want,

And bitterest scarcity,

And then a harvest

Crop of plenty comes.

But thou, oh, Rupé,

Hast the power to

Choose or cast aside

The choicest that

The earth can give.

When sleep enwraps

Thy frame, the medium

of thy spirit comes

And shows thee what

The staff of life would say,

Thy omen staff, if

All alone, tells what

Heaven's fiat is of

Famine, and of

Universal death to man.

The following poem is from the heart of one in dire distress because his sons have fallen in battle, and whose wife and daughters had fallen, too, as victims of famine and pestilence, during his absence in war with a distant tribe. No part of the great drama of Job is more touching or more forcibly put.

The tide of life glides

Swiftly past and mingles

All in one great eddying foam.

Oh! heaven now sleeping,

Rouse thee. Rise to power. 


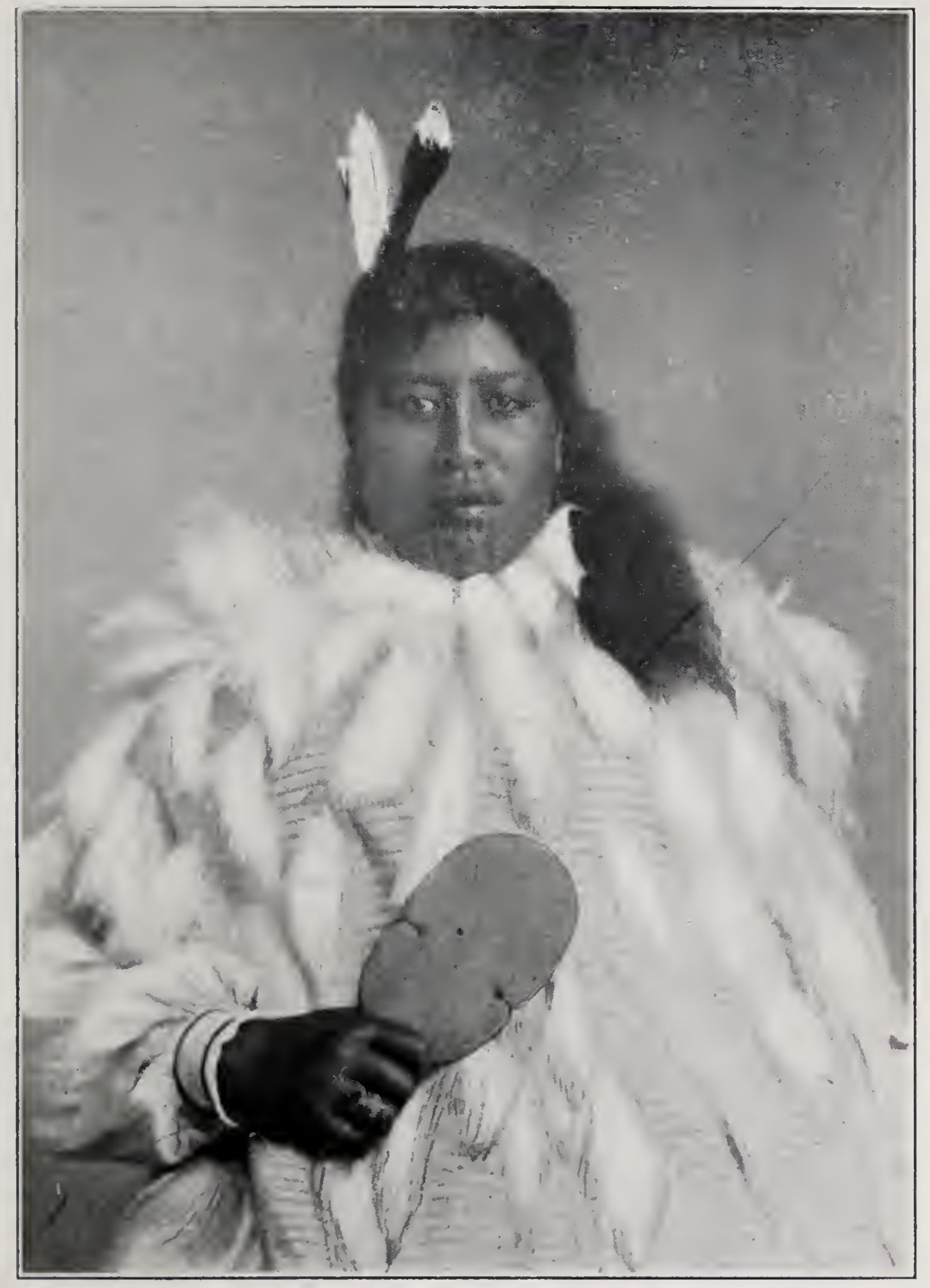

HIROINE: OH: ROTORI'A 



\title{
MAORIS OF NEW ZEALAND
}

\author{
And Oh! thou earth \\ Awake. Exert thy might for me \\ And open wide the door of \\ My last home, where calm and \\ Quiet rest awaits me in the sky.
}

The sun declines and hides

In dusky eve. So will I

Leap forth to the sacred isle.

Oh! stay, thou voice of $\mathrm{my}$

Own sacred bird. My heavenly

Bird now far up in the sky,

Whose voice with double

Sound now weeps.

Smite me and thrust me

Into blackest night and

Endless gloom, where I

May stay upon the border land

And rest submissive

To my fate.

There is an interesting legend which embraces the story of Hine-moa, the daughter of Hine-maru, who, falling deeply in love with a young chief, Tutane-kia, who dwelt on an island in Lake Roto-rua, and quite captivated with his music and his playing upon the horn, swam in the night from her home to his island, where they became man and wife and the ancestors of all those who dwell along the shores of Lake Roto-rua.

The following ancient poem refers to that event: 
Oh, gentle air, blow from the north, Blow softly, gently on me now, And I will gaze and watch to see The loved one coming from afar.

Oh! turn and look this way, And make me glad for thee, Then here I still may stay And wait for thy return.

I watch the cloud that hovers O'er the home of my beloved, While fond regrets must moan Thine absence in the north.

My heart felt certain thou Wouldst be all mine for ever, And now that thou art here, The days are always bright.

I spent some time around the shores of this very popular lake, particularly celebrated among the Maoris by the historic event which I have just given, as these two people were regarded as belonging to Maori nobility.

We took a small steamer and crossed to the other side, towing at her stern a skiff, perhaps twenty or twenty-five feet long. We landed at the mouth of a small river or creek. One man paddled the skiff up stream something over a mile. The rest of us walked the distance along a path through the wood. At the distance named above we came to a rapid river rolling directly up out of the earth. 


\section{MAORIS OF NEW ZEALAND}

It is probably fifty or sixty feet across, quite circular in form. One can walk all the way around it on perfectly dry ground. The current is so rapid that no one standing on its edge could throw an oar, no matter how strongly, so as to impel it down into the water its whole length. Nor can anyone dive entirely below the surface, no matter how expert at diving; the current forces him back so quickly that he cannot possibly go entirely under.

Where this river enters the earth, or what may be the length of its underground course, no one can tell. It is supposed to be supplied from the bottom of one of the lakes some miles away.

Sometime in October of each year many thousands of fish, absolutely blind, with no semblance of an eye, come up with the stream and are carried down the river into Lake Roto-rua. The natives, however, catch very many of them with nets, and dry them in the sun for winter food.

The river rolling up from depths unknown is of sufficient volume to make a stream deep enough to carry five or six of us men down in the large skiff to the lake.

New Zealand has a large number of natural objects to make it a very interesting country for tourists.

There seems to have been among these people a common and natural love for poetry and song. 
Song seems to have entered into all phases of ordinary life, domestic or social, in times of peaceful cultivation of the soil, or in times of war preparation or of belligerent action.

The following song was commonly sung during the cultivation of the land and the planting of seed, to ensure protection to the growth of the crop from the ravages of insects or inclemency of the weather:

My spirit trembles in this world,

While down from Rehia Hill

Lightnings flash and winds descend,

I offer sacrifices demanded.

My enemies are these,

The earthquake and caterpillar,

And all devouring insects,

Coming from Wero-ti-a.

Oh! may the yams and kumera

And taro now fall out,

The girdle which encircles

The breast of Wahi-roa.

May the god of man

Deprive all enemies of power,

For I now am at my work,

And my crops am planting.

Moisten my plantations

And cause my crops to grow, While I chant my sacred song

To Him, the one supreme. 


\section{MAORIS OF NEW ZEALAND}

In the next song, with its refrain, there is an evident idea of a knowledge of the origin of preparation necessary for making the earth ready for the abode of man.

Separate heaven and earth, That they may be parted.

Sing the resounding song,

Sing the resounding song,

Separate the damp part,

Sing the resounding song,

From the part that's dry,

Sing the resounding song,

That parting may take place,

sing the resounding song.

Separate the darkness,

Sing the resounding song,

From the sun and brightness

Sing the resounding song,

Separate Tu and Rongo,

Sing the resounding song.

Where it was desired to set certain neighbors or others at variance, for the purpose of revenge or war, incantations were used, such as I give below, this one being attributed to an old female goddess of the first generation of the lower world. Like many of their poetic creations, the original author is entirely unknown.

Rough be their skin, So altered by dread, As brambles and nettles 
Repugnant to feel,

So change for each other

Their love into hate.

With dire enchantments

Oh! sever them, gods,

And fill with disgust

To each other their days.

Engulf them in floods,

In ocean and seas,

With dire enchantments,

Oh! sever them, gods.

Let love and regret

For each other be hate.

Nor affection nor love

For the past live again.

There seems to have been in the minds of some of their poets, at least, an idea of a Deliverer for man from the darkness of this world, leading the soul up into the realms of greater light and happiness.

Stay, omens, stay, the

One Supreme has come,

And signs now tell

Of his disciples near.

They come, and peering

Forth, they gaze into

Vast space of sparkling

Beauty, and of good. 
I, the scholar, hold the

Sacred stone of power,

Soul of power, soul

Of earth and heaven.

Accept delight and

Ecstasy unlimited,

Hold all beauty, but

Let it spread around.

The soul now climbs

And high ascends to

The soul of the Supreme

And his disciples.

Oh, heaven! the soul

Is far above, in

All creation's space,

In light supreme

And in the blaze of day.

A father's lament for the loss of his children.-Their parental affections were very strong. They were also solicitous for the morals of their children.

I bow my head as

Droops the tree of fern,

Weeping for my children.

My child, so often called,

My children. Oh! my children.

Gone. Yes, gone as

With the mighty flood.

I lonely sit, 'midst

Noise and crowd. 


\section{MAORIS OF NEW ZEALAND}

My life ebbs fast, My house is swept, Clean swept for ever.

The shining sun has nought

To gladden now.

But I will bow me

In my house and

Ponder in despair.

My heart will then

Forget the deeds of man.

Oh! was it theft that

Makes the moon to wane?

Or was it theft that

Makes the avalanche?

Or was it they who

Caused my children's death?

The old vocal Maori music differs very widely from our music, although now and then one might hear a near approach to some of our more simple chants. With them every song or piece of poetry must have its own proper tune and must not be sung or recited to any other but its own.

They have other songs which were sung only by the women, whose voices were very remarkably mellow and soft, with always a pleasing effect. The time is slow, and the cadence mournful, but conducted with a taste we could not have expected from such a people.

The children seem to be initiated at a very early age into 


\section{MAORIS OF NEW ZEALAND}

keeping in their songs the strictest time. They sing with much spirit and melody.

They enjoy their songs more if accompanied by the flute. Their tongue is not harsh, and whatsoever qualities are requisite to make a language musical are not lacking in them. Their delicacy of ear in the distinctions of tone and in their diligent efforts to improve their musical knowledge and musical permanence reveal a very creditable musical faculty. 

THE STORY OF PONGA 



\section{THE STORY OF PONGA}

\section{LOVE AT FIRST SIGHT AND MATCH MADE}

LONGFELLOW never discovered in the history of the courtship of Hiawatha anything more thrilling or sublime than will be found by the reader in this story of Ponga (pong-eh) and Puhi-huia (poo-e-hoo-yeh).

These young people were the offspring of genuine cannibal stock, and their love drama was enacted in those good old cannibal days which some of the older, still remaining, mourn as gone forever.

Ponga had come from Awhitu (ah-wee-too) to visit for a fortnight the young people of the larger tribe at Mount Eden, one of the natural features of the now beautiful city of Auckland, New Zealand. The young bloods of higher rank, that is, the sons of older chiefs, had boasted that they would capture the heart of Puhi-huia.

Ponga was a modest boy of few words. In the hakahaka and kami-kami games, the performance and gestures and grimaces of each were so perfect and enchanting that these two fell violently in love with each other. Puhi-huia being of the very highest rank, the noblest Roman of them all, could not, according to their strict rules of etiquette, 


\section{MAORIS OF NEW ZEALAND}

come near or in any degree associate with Ponga, a man of low degree, because the son of a chief third or fourth removed from the oldest born of the old chieftain's family.

He could not sleep, he went and sat in the moonlight on a rock near the dwelling. Hearing a footstep, he asked, "Who is this?" The answer was, "It is I, your slave." Ponga said, "How strange that I am not able to sleep in that house!" His attendant replied, "You have fatigued yourself in the haka games and in making grimaces, but as the proverb says, " $\mathrm{He}$ who fishes for the sprat may sleep, but he who fishes for the whale must keep awake." " Ponga said, "Yes, but it is also strange that I have lost all thought of Awhitu matters." Said the attendant, "To what do you allude?" Ponga said, "Having regard to deeds of past times, I feel that I must be cautious in my conduct. The evils which in former days came on the people of this tribe have never been avenged." The slave answered, "Yes, but we came here as guests, and all are quite young. What can rats do?" Ponga said, "It is so, but the old proverb says, "Though the mokoroa grub be a little thing it can cause the big Kauri tree to fall." "

The slave replied, "We came here for amusement and we presume upon the fact that peace is made between the tribes." "Yes," said Ponga, " provided that all our party 


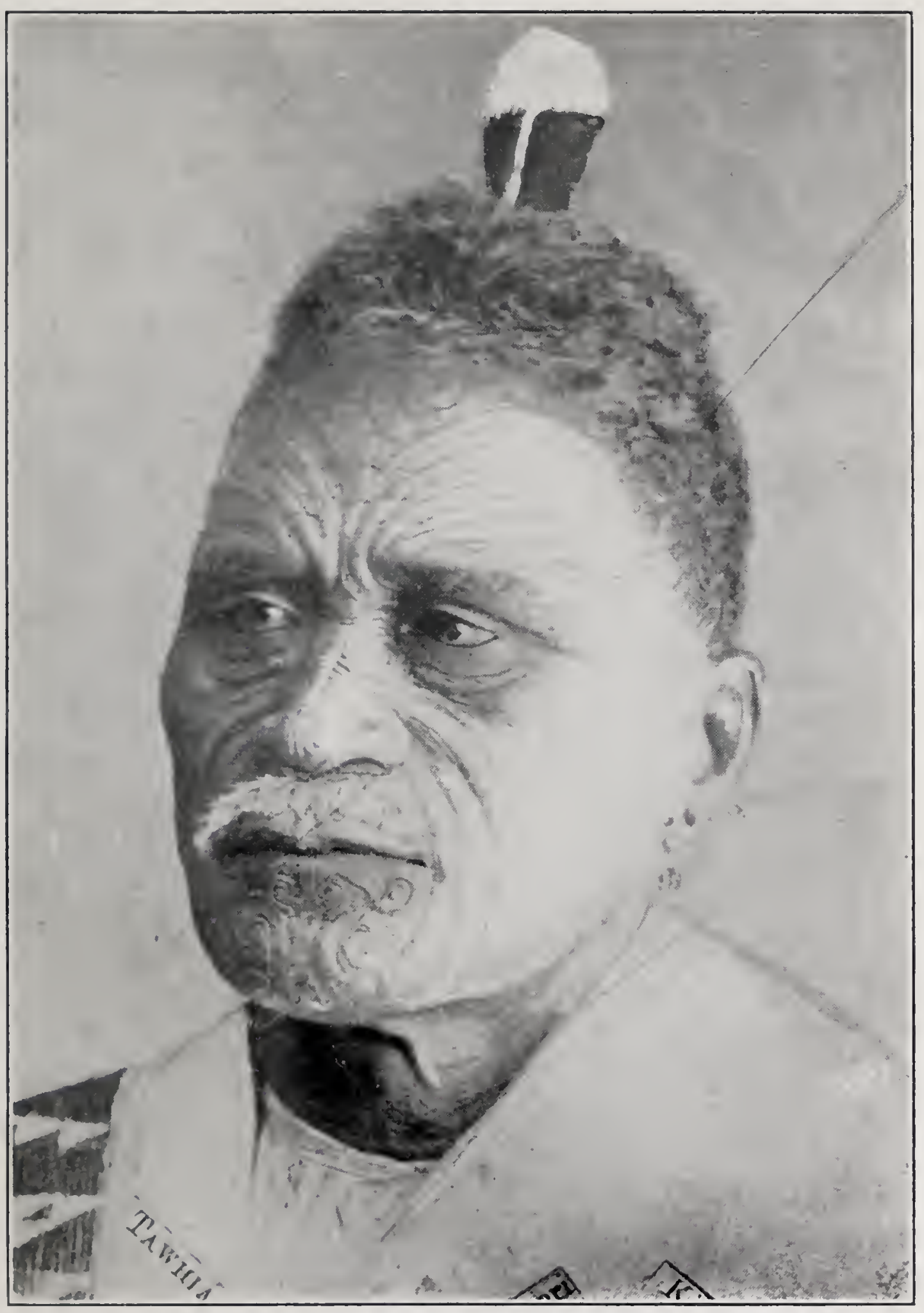

MAORI KING

'TAWHA ('TA-WHEE-A) 

keep their hands from touching that which is not theirs; if such were to take place evil would come on us all." The attendant said, "You chiefs only dare to touch the sacred things of the pah (village). Such as I am would not commit such an act." Ponga said, "Do you mean, to touch and take, that is, to steal property?" The slave answered, "Not quite so; property is property, but there is also such a thing as sacredness in property that has life." Ponga asked, “Do you allude to Puhi-huia?” He answered, "Can the fact be hidden that the eyes of you, of noble birth, glistened and flashed when looking at that young woman when she made grimaces in the games in which she took part?"

Ponga said, "I am quite bewildered. Let us return to our homes, lest evil befall us."

After sitting in silence a long time, the slave said, "Ah, friend, I have a thought. Do you agree to what I propose, it will be good; if you do not, you have a right to reject. Let us return to the house; if you sleep, well and good; if you do not sleep, it will be good, but be brave. Let your spirit live in you; food is food, eat it. Talk and laugh, and let the sorrow that is in you be smothered by your determined will; let it be kept hidden from the knowledge of others. On the evening of the coming day, feign to be thirsty and call for 


\section{MAORIS OF NEW ZEALAND}

me; call loudly, and order me to go and fetch you water. I shall not hear you, and it will seem as if I were not heeding you. The mother of Puhi-huia will perhaps ask her daughter to go and fetch you water, which would not be degrading to her, seeing you are suffering for it, and because you are a chief and a guest. If the daughter obeys, you can arise and follow her to the spring; but be sure and let everyone awake hear you say, 'I wonder where that deaf and stupid slave is. If I can find him I will crack his skull." "

All was carried out to the very letter the following night. The mother said, " $O$ daughter, are you so deaf that you cannot hear one of our guests calling for water? Can you not feel some sympathy for him and go fetch him water?" Ponga left the house as soon as she had gone, vowing vengeance on his disobedient slave, ending with a proverb that the day may be long but the night must come at last. Puhi-huia sang, to strengthen her heart, an old song, common in her tribe, having come down from her ancestors through many generations:

Shoot up, oh! rays,

Of coming days,

And moonbeams, too,

I wait for you

With song resounding. 


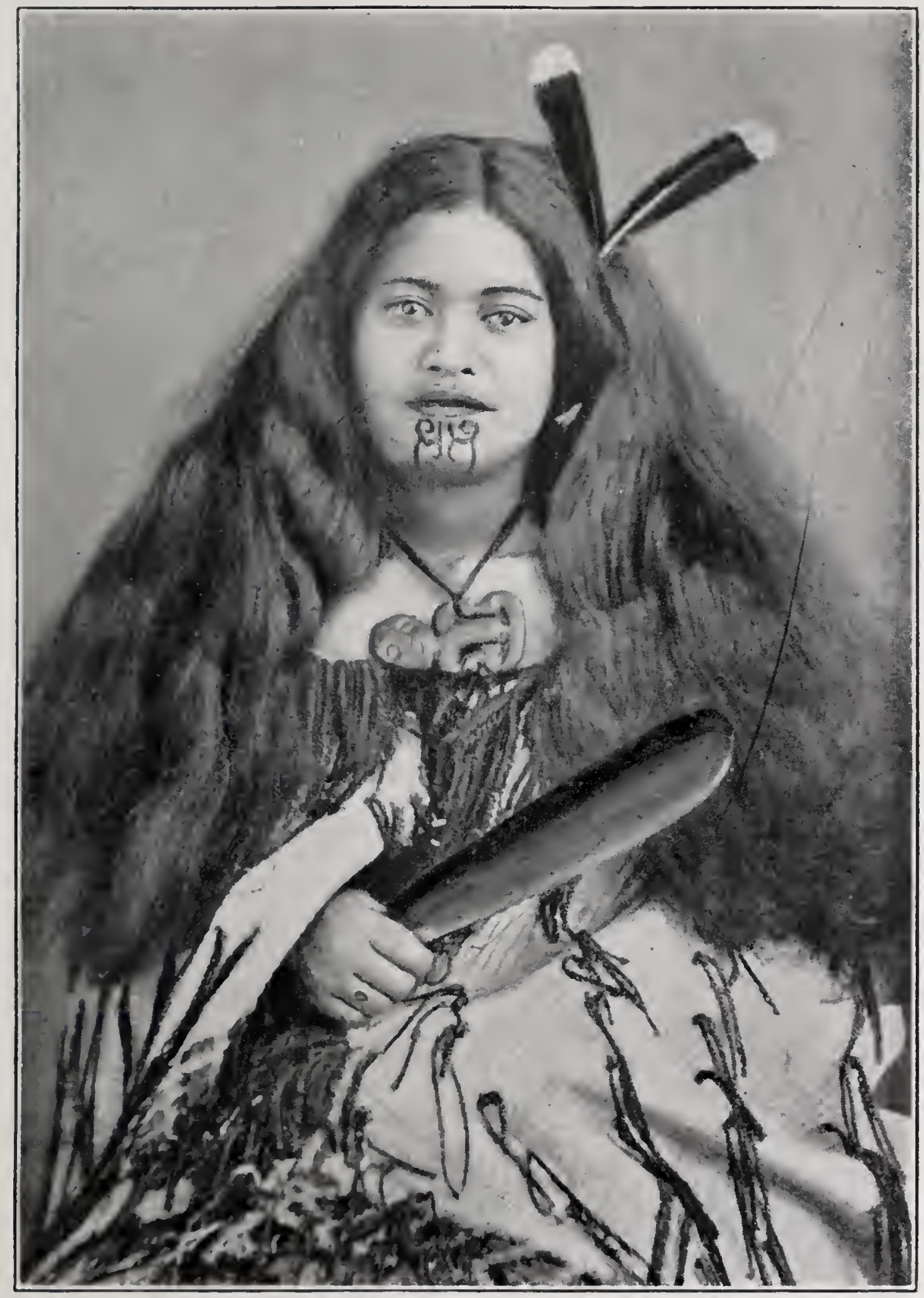

PARE; WHABRERONQONNA

Ormament upon her nech is a sign of nobility she wonld not lare to wear it if she conld not establish her right to do so. 



\section{MAORIS OF NEW ZEALAND}

May you shine forth

To light the path,

Which now I take

With song resounding.

That sure I may,

With path all clear,

Now travel on

With song resounding.

Along the road,

Which echoes still, And still vibrates

With song resounding.

Ponga, guided by her song and light of her torch, overtook her at the spring. She was in the act of lifting the filled calabash (gourd) from the water, when she discerned Ponga near her. She asked, "What do you want?" He replied, "I want a drink." She said, "I came for water for you. Then why did you not stay in the pah (village), and I would have taken it to you." He answered, "My word in regard to thirst is true, but my thirst is that of the heart, and it is from within that I feel a longing for you." She heard his words and thought, "Why, he loves me!" They sat down and talked. Ponga said, "My home at Awhitu is famed for its fish and shellfish; here you have but fern root." She said, "We have fish in our pah from the east coast and the west coast-the coast of which the 


\section{MAORIS OF NEW ZEALAND}

proverb says, the coast where a female may paddle a canoe." He replied, "You may have much fish and food in your pah, but what food does the heart obtain?"

She said, "Quite so; maybe at your home young chiefs delight themselves in sports." He replied, "That is true; then return with me, that you may behold and join in our sports." She said, "The matter rests with you; on the night preceding the day of your departure, command your servants to go to One-hunga (o-ne-hung-eh), our seaport, and cut all the lashings of our canoes, and keep your canoe well out and afloat, so that when I leave with you our people will have no canoe with which to pursue us. Now go in front of me and arrive first at the pah; go quickly." He entered the house and asked, "Has any water been brought, for me?" He was told, "No." He said, "I have not been able to find that stupid slave; I will yet crack his skull."

He was repeating proverbs galore and nursing his wrath to keep it warm when Puhi-huia entered at the other end of the house. Her mother said, "How long you have been!" She answered, "Is the road so short, or does the sun shine, that you should wonder at the time I have taken?" 'The mother said, "Take the water in your calabash to Ponga, who has felt the pang of thirst so long in awaiting your return." 


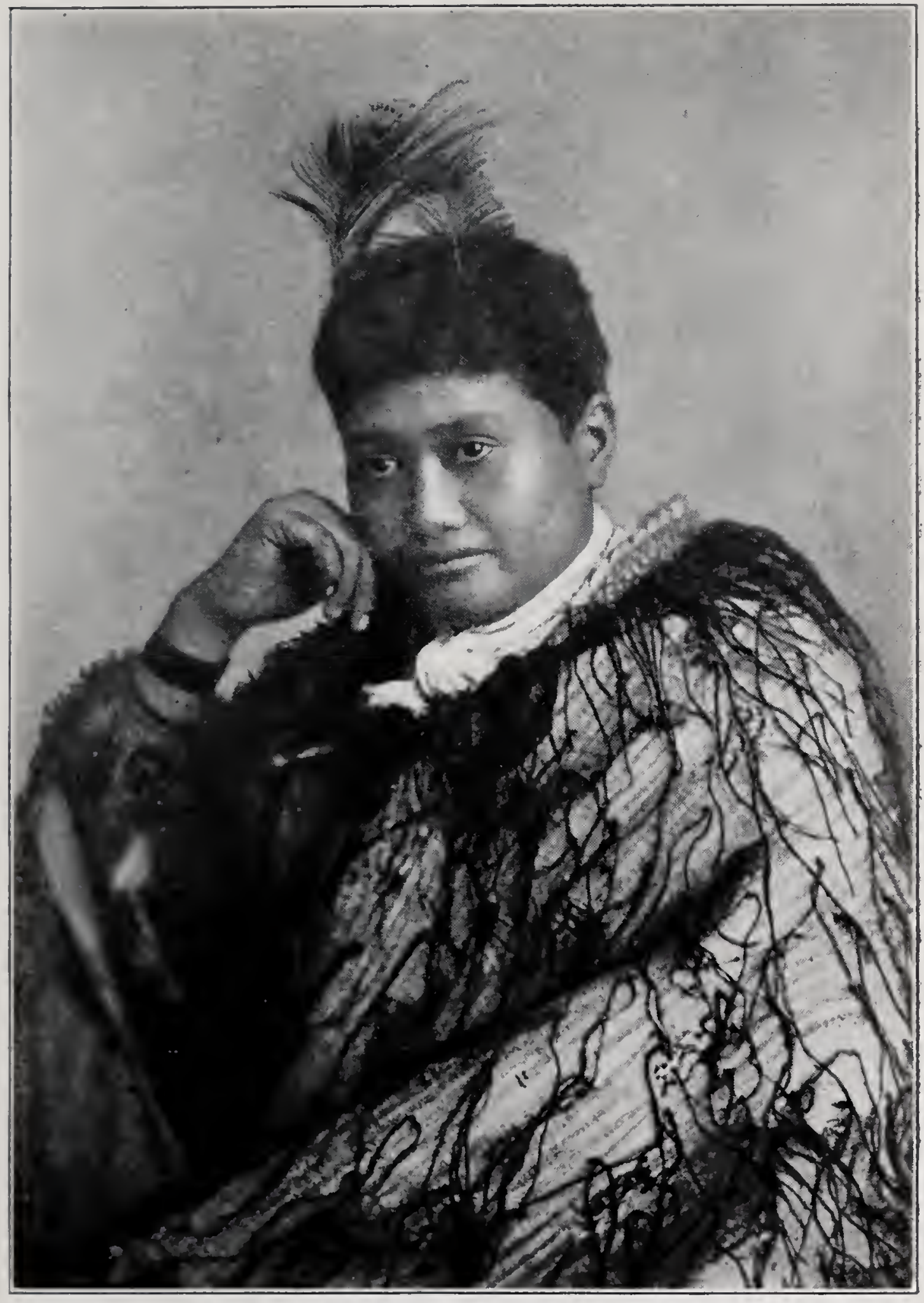

MARI: PA-O-RE:

A Maori Fiducated in Jinglish 

She took it, but as he was a chief he could not drink like a common person, directly from the calabash, but formed a cup by placing his two open hands together into which she poured the water, which he drank. The night before their intended departure he commanded his servant to go with his associates to One-hunga and to cook food and make all necessary preparations, but especially to cut the lashings which held the top sides of the Mount Eden canoes. All was done as he directed.

The next morning the guests put on their belts and rugs ready for departure. The head chief of Mount Eden took his mere-ponamu (greenstone heirloom weapon) and gave it to the young chief of supreme rank of Awhitu, who in return gave his also to the great chief of Mount Eden. This was according to ancient custom. This exchange of weapons was a ratification of any terms of peace which might have been agreed upon by the tribes. 


\section{THE RUNAWAY.}

When the young people set out, Puhi-huia accompanied them for some distance, when her father called out, " $\mathrm{O}$ girl, come back. It is only the insane who go so far. You will be called a person of low birth." If she heard her father's voice she certainly did not heed. Her female friends immediately turned back on hearing the words of their old chief, her father. Puhi-huia, driven by the power of her love, and the great longing of her heart, flew towards him with whom were all her affections. She came up at length to the Awhitu people and went at once to the side of Ponga. She said, "Let us proceed quickly; life is in the power of our muscle, and by this we shall gain the canoe." They all went swiftly on, like the feather of a bird driven by the wind, like the weka escaped from a trap, like the pinga along the coast driven by the fierceness of the blast. The Mount Eden people saw, from their pah, Puhi-huia join the departing guests. Each warrior seized his weapon and joined in the hot pursuit. Not in command of any leader, they jostled each other in a combined mob, many tumbling to the ground in their vengeful haste. Seeing their princess had embarked with their late guests, they rushed to their canoes to drag them to the water. 
As was the custom, a line of men and women on either side laid firmly hold of the craft to launch it for pursuit. One gave the command, "Move it, move it," while all responded, "Slide on, slide on." As all the lashings of the top boards had been cut, they at once tore away and left the hody of the canoe standing unmoved. Some of the people fell head over heels, and some went sprawling; others were held down by the weight of the boards, with their limbs badly bruised. These rose to rub their arms and legs, and seeing the sorry plight they were in, they shook their fists and made grimaces at their departing guests, repeating proverbs by the dozen.

\author{
Go, go, go, \\ The sun may rise, \\ And the sun may set, \\ But we will see you later.
}

The guests paddled towards their home full of glee, proud of the young woman of high rank who had come with them. Ponga's slave was happy. It so happened that as Puhi-huia was one of the last to enter the canoe she sat near the young chief of highest rank who had received the greenstone weapon from her father. He took it from his bundle and showed it to her and said, " $O$ young woman, there is the weapon of your father given to me: accept it 
as your gift to our lords of Awhitu." She said, "Am I a man that I should hold a thing so sacred? It is for you in the male line of supreme chiefs to hold such things. I will not take it, lest in days of evil it may be said that the evil was caused by the hand of a woman holding a thing so sacred." He answered, "Accept it, and let it be your gift to our head chief at Awhitu. Will it be right for you to go into his presence without a gift in your hand?" She replied, "Should there be an exchange twice repeated? No, all I shall take with me will be that which I already possess." He said, "Who received the scented oil taken by cur young people to your pah?" She answered, "It was in the open courtyard and for all the people. I did not receive any of it." He said, "I asked my question as I thought your remark respecting a double exchange alluded to the scented oil." She replied, "You are impertinently inquisitive; you can see, and have seen, that I came here with Ponga, yet you ask questions." She arose and went and sat next to Ponga. The timekeeper for the rowers sang songs of his own composition:

Pull on, oh, friends, pull on,

Put down your paddles deep, How leaps my fluttering heart,

As flashes of such brightness, Gleam from out thine eyes.

O, Puhi-huia. 


\section{MAORIS OF NEW ZEALAND}

Though thy fame had spread

From Eden's mount to distant lands,

Yet thou dost deign to live

With us, in humble home,

O, Puhi-huia.

They paddled on; when halfway across the outer harbor the young chief once more said, "O young woman, accept this your weapon; it is the weapon of your ancestors, it is the famed weapon called "Kaho-tea." " She said, "Hold your own weapon; you may ponder your thought and I will ponder mine." He replied, "Then let us cease our contentions in respect to the weapon of your ancestors. Peace was made in days of old, and there is food in the fish of the sea we are now crossing. You are not ignorant of the fact that death has come to many because of these fish. I did wish to put this heirloom into your hands that I might have the honor of protecting you." She answered, "You of us two are the more ignorant. You have seen that I was in the protection of Ponga. He is the one known to my heart and whom my love embraces. He will be my protector." He said, "Then do you say that Ponga is to be your lord?" She answered, "If so, what then? It is as you say." He said, "It is well ; let it be as you say."

She answered, "Who are you? And what is he that I should not take him as my lord? And what can you do? 


\section{MAORIS OF NEW ZEALAND}

Are you so sacred that you cannot work in the cultivations? Of such as Ponga it is said, 'The brave in war never lose their fame or power.' I and my heart have found one for ourselves. If evil comes, only death shall part me from Ponga."

The canoe neared the shore. Those on the beach waved their garments and said, "Come, oh, come, and welcome, to our home from a distant land, all our returning children." The young chieftain of highest rank stood up and called to those who had assembled. "Whom do I see sitting on the shore?" They answered, "We, your ancestors and parents, are all here." He said, "Stay where you are and hearken to my words. I, your child, have had a narrow escape from death. All the young people of our party conducted themselves at Mount Eden in a quiet and peaceable manner. but Ponga acted to me like a murderer. Here is that young woman, sacred and of most supreme rank, daughter of the lord of Mount Eden, brought here by Ponga. He did not tell me at the time that he was about to commit this theft, or I should have made him to desist. When we had bidden farewell to our Mount Eden friends, and had got near to One-hunga, Ponga, unknown to us, was in the act of taking this young woman from her home.

"All the warriors rose and with their weapons fol- 


\section{MAORIS OF NEW ZEALAND}

lowed us. I was bewildered by the suddenness of the fright when I saw that we were being pursued by an enemy. They at once rushed to their canoes to drag them to the sea to follow us, but your two tribes have been so long at peace the lashings of the top sides of their canoes had become rotten, so that the top sides came away and let the people fall one over the other on the ground, and thus the rotten lashings saved my life. I am angry with myself for fleeing from them and not sending this young woman back to her home. Daylight is light in these days, but now darkness is deadly gloom, and by tomorrow your enemy will be here. If you are brave, well and good; if not, you will be lost, like the extinction of the Moa, and Ponga will be your murderer."

As soon as he ceased the head chief arose. All others sat in silent dread. The old chief said, "Welcome, welcome, take the girl back to her parents. You are right: because of long years of peace the lashings of the canoes had become rotten and thereby your life has not been taken. I will not allow the girl to break the bonds of peace."

The canoe was yet a little way from the shore. Puhihuia arose and waved her hands for some time towards the crowd on the shore. She stretched her arms at full length and said, "O people, look at me." All the people uttered a 


\section{MAORIS OF NEW ZEALAND}

low moan of admiration at her noble figure and attitude. She was a fine-looking woman, tall, with dark curling hair, and supple as a sapling of the forest. To those on the shore she said, "Your anger against me is not just. You are right in blaming me, as I may be the cause of evil which may fall on you; but you are not just when you falsely accuse Ponga. I came here of my own accord, but I blame you for this. Why did you not see how beautiful your child Ponga was and keep him at this your home? If you had allowed only his companions to come I should still be at my home. You allowed the agitator of my heart to come near me, and I could not restrain my feelings, but rushed madly into love because he is so good-looking. I am not to blame; you laid your plot to murder me."

She ceased, and with one bound went into the water and swam towards the shore. Those in the canoe sat like so many beings bereft of their senses, and not one of them uttered a word. She swam till she could feel the ground beneath her feet, and then stood in the water, which came to her knees. Again she spoke: "I, Puhi-huia, stand in your presence. I alone sought for and have found that which shall be mine. I am not and will not be amenable to the order of anyone who says, 'Do this,' or 'Do that,' and if you persist in saying that I must return to Mount 
Eden, by the time the midnight comes to this day I and Ponga will sleep in the foam that the sea surges make on the bar of this harbor. I shall not come on the land; the land is yours, the ocean is my home."

Not a voice was heard from the shore, save the deep and loud wail of the sorrowing women. The young chieftain spoke again to those on the shore: "The crop takes one ear before it is ripe, but the thoughts of man are planted and the crop is here at once. Why, old men, do you sit in inaction? The Mount Eden warriors will follow. Does the year ever remain calm through all its days? No, there is summer and then winter. The sun shines and then thunder is heard. Are you ignorant of the lightning of heaven?" Ponga waded through the water to his beloved and stood beside her.

Again the old chief of Awhitu arose. He did not utter a word while passing from one end of the beach to the other. Then he turned quickly and ran along, kicking the sand into the air so that it fell in dust behind him. Then he exclaimed, "Oh, woe! Oh, woe is me, $\mathrm{O}$ my offspring, the world is all a blaze of fire! Come, my child, O daughter of high birth. Go where you will, death is there. Live where you like, death is there. Plant your crops, death is there. From the days of 


\section{MAORIS OF NEW ZEALAND}

Maui (mow-e) death has been everywhere. Do you think that you will not die? O my child, all is death in this world. Come to our home. O young woman, welcome to these of your ancestors. Evil or death has not its origin with you. Death and evil are of old. O my child, your ancestors have never slept on a mat on the foam of the sea. How brave and daring you are! Come, $\mathrm{O}$ child of noblest birth, come, and you and I will live or die together."

This last word meant that he would sooner die defending her than allow her to be taken back against her will. As the old man ascended to the pah, the very old men and women there came out and waved their garments and called the welcome as of old. The old man led Puhi-huia to his house, followed by Ponga. Food was cooked by his attendants and carried and laid before the young people returning from Mount Eden.

It was borne from the ovens by the young people, who formed in line, three abreast, carrying the food in baskets and singing all in chorus:

It is thee and Ponga,

Puhi-huia and Ponga,

Tender, tender,

Rich and ripe and mellow,

Red and rare and yellow,

Let the feast be eaten,

Come to our pah and welcome. 


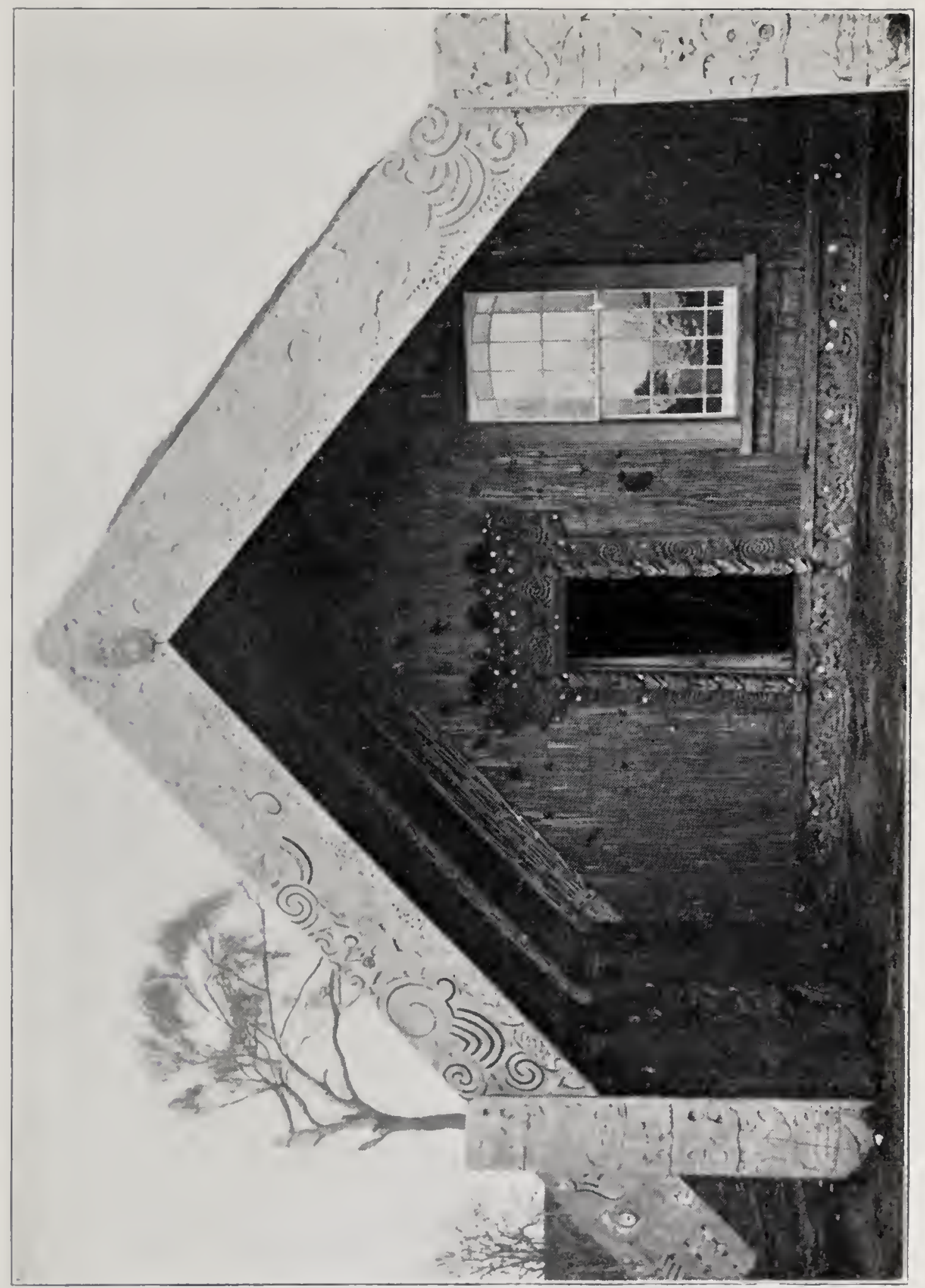

至 



\section{MAORIS OF NEW ZEALAND}

When the food had been placed in a heap, the old chief took a green bough and, touching it, said, "This food, this food, this food is for all the tribes in every place." He sat down, and Puhi-huia arose and, taking a fern stalk, broke it in short pieces and stuck them at intervals along the pile. Then she went to the young chief whose life had been so wonderfully preserved by the rotten thongs of the Mount Eden canoes, and taking the mere-ponamu (me-re ponam- $u$ ) in her right hand she waved it above her head and said over the first division of the food, "This food, this food, is for the Awhitu people, for each and every sub-tribe within all their boundaries." The old chieftain again arose and, taking his green branch, struck the portion that was nearest him, and said, "This food, this food, is for Puhi-huia;" and another, saying, "This food, this food, is for all those of Awhitu ;" and yet another, saying, "This food is for all of Wai-ka-to and for all them who live within its boundaries;" and the last portion, "This food is for all in any place through all the world."

Puhi-huia arose and said, "Where is the man who was deaf to the call of his lord, calling for water? Stand up and let me look at you. Now, are you the man who brought not the water for your master?" He answered, "Yes." She asked, "What is the most requisite accompaniment of 


\section{MAORIS OF NEW ZEALAND}

food ?" He said, "Water." She replied, "It is by your conduct I am here; you were deaf to the commands of your lord, and I had to fetch water for him, and so I learned his love for me. It is for you to distribute the food allotted to me and in my name." The attendant went near to the food and said, "This food is for Ponga and for the many young chiefs who paddled to visit Mount Eden."

A chorus of voices cried out:

Right, right you are, You have acted nobly, Give the food for Ponga

To his worthy friends, Who helped to bring

The noble born to our home. 


\section{COUNCILS HELD.}

Tre old chief who had led Puhi-huia up from the water said, "What is to be our policy? Let us meet in the visitors" house and hold a council." One of the young chiefs said in the council, "Was it I who brought the noble-born from her home? Why should I stand in dread of the weapons of Mount Eden?" Another said, "She has come of her own accord: let her harvest her crop, or, in other words, lead us to battle." The young chief who had received the heirloom from the great lord of Mount Eden said, "Here is Kaho-tea, the weapon of the father of the girl, given me to bind more firmly the terms of peace between our tribes. Ponga did not heed this token. He stole the daughter from her parents and brought her here. If the evil had originated with me I should take a part in our defence, but as it has come from the act of one of low degree, why should I be killed for naught?"

Puhi-huia, having arisen, said, "My ancestors and fathers, the evil of which you speak did not originate with Ponga. You were yourselves the first cause of all this action. You allowed Ponga to visit the home of my parents. Why did you not keep him here with you? If only your other young 


\section{MAORIS OF NEW ZEALAND}

chiefs had come I should have still been at Mount Eden. To any of them I should have said, 'I will not go with you.' Why should I not charge you with being the cause of the evil for which you blame Ponga? He is not the originator of my action, nor did he utter one word of advice or order. I alone had the thought and acted upon it, and I am here; and if the war party which you fear should come I will grimace at them, and though I am but one and Ponga is but one, what then? Do you think I will return to my home? No. This is my adhering to Ponga even to the world of spirits." The head chief arose and said, "It is right, $\mathrm{O}$ tribe, you have spoken. If I and my daughter are killed, who can order otherwise?"

No one dared say more at the conference after this great chief had spoken. Some were afterwards heard to say; "The words of our great chief are just. If the young woman loves Ponga, why should we not support her in her determination? If war follows, let us all be brave."

It was now grey dawn. Each warrior, bound round with his war belt, brought out his weapon. All knew the meaning of their chief_- "If I and my daughter are killed, who can order otherwise?" He meant by these words that he would not allow Puhi-huia to be retaken without resistance even with death. The sun had scarcely gained the 


\section{MAORIS OF NEW ZEALAND}

meridian when a large canoe full of warriors came close to the shore.

Puhi-huia went near to them and said, "Cease to paddle; stay where you are. You have come as the advance-guard. Who is supporting you?" They said, "All our tribe is behind us." "And what is the object of your coming?" They replied, "That you return to your home." Puhihuia said, "Return, go back and tell them that if they come they can only see me as you see me. I shall not return to my home by force alive. Do not send the people to the world of spirits by war; let mine be the only death. My husband Ponga will not sit in silence; he also will speak. I have found for myself that which I like, and shall hold it even to the dark world. I am not yet the wife of Ponga, but if my parents and my people will come to this pah when next the moon is full, Ponga will prepare them a feast. If they come guided by the god of war they shall not see me alive; I will meet them in the world of spirits."

She ascended to the pah, and they turned their canoe and paddled for One-hunga. When Puhi-huia had said to the advance-guard that she would die with Ponga rather than be forced to yield to their demands, all the women on the shore said, "Even so, such is the constancy of the nobleborn, she will not act in a trifling manner. She will even 


\section{MAORIS OF NEW ZEALAND}

go to the world of spirits rather than leave him she loves; such hearts are never fickle; even so does the noble-born act."

The message sent by Puhi-huia was delivered to the tribe. A council was called. All the young chiefs were present. One young chief gave a loud cough to attract attention. He rose and said, "My parents and ancestors have for many years nurtured that to which my heart was inclined, but when my valued property was full-grown and the bloom of summer beautified it, my junior in rank came and took it away. Why should I not feel anger? You old people have felt the joys of life and its power. Allow us of younger years to feel the same; allow us, then, to go and bring back by force our most valued one."

Another young chief said, "I have noticed that when the Kaka parrots take their flight as winter comes, there always is at least one red Kaka which takes its flight with the second flock. Is it wrong for the red Kaka to fly with that flock? You propose to compel Puhi-huia to return to her home. If she has determined to act she will do as she says, and if you go to fetch her she will not return while she is in life."

A female attendant of the absent girl said, "I have been an attendant on Puhi-huia through all her life; her 
attendants have joked with her and told her she could have any of the young chiefs of our coast. Some of these have tried to win her, but she would not listen to them. She is a most determined young woman, and nothing will turn her from her purpose."

The meeting continued all night. Most of the speakers advised that she be allowed to choose for herself. Some, however, argued strongly in favor of the use of force to bring her back. As the day was dawning, the mother of Puhi-huia said, "The mind which swayed and the acts performed by her progenitors will be followed by Puhi-huia. I am a descendant of Hotu-nui. I was not one to whom my tribe said, ' $O$ daughter, such a one must be your husband.' My lord with whom I live was of my own seeking and choice. I defied all my brothers. The one I loved was at Rara-tonga. His parents and chiefs came to our fishing-grounds, bringing him with them. He had just been tattooed. When I saw him my heart was bewildered by him. How brave was the one I loved! My spirit was dead to all other objects. I came to this Mount Eden and lived at his home. On the night of the day on which we arrived, I went out to the courtyard and proclaimed to all the people, 'I will not hide the secret, I will have my husband.' I found him at Rara-tonga; all the people can 
understand what I mean. The Rara-tonga tried to make war with the Mount Eden people, but they did not succeed. Puhi-huia will do as she has said. If we attempt to take her by force we shall see her but one day in life, and no more till we meet her in the land of spirits. She will do as she says; there is not any power that can command her."

The mother of the young chief who first addressed the meeting said, "Yes, the words of Puhi-huia's mother are true, but the young chiefs of this pah are stupid. Yes, you are the veriest cowards, void of daring. Do you think that your bare, untattooed faces will ever gain a wife? Why is it that Ponga is so noble-looking? He is tattooed, and he looks grand. Yes, it is quite right that you should lose your noble young woman." Others spoke, but all were agreed that it was better to allow their princess to have her way as to her choice of a husband.

When the morning repast had been eaten, an old priest stood up and said, "How foolish is this people! We are invited to a feast: then why do we not inform our friends at Awhitu that we will go? Do you not feel a longing to smell the savory scent of sharks' flesh permeating your breath? I say, 'Send a messenger to tell Puhi-huia that when the moon is at the full we will be there by invita- 


\section{MAORIS OF NEW ZEALAND}

tion." All the people agreed to the proposal thus made, but the mother of Puhi-huia said, "I and my war party will start for Awhitu." She went to her house and took her most valuable garments, gourds of oil, down of the albatross, tail-feathers of the huia bird, and garments made from the kiwi, and all else esteemed valuable in those days, and putting them all into a basket she called one of her female attendants and told her to put them on her back. Then she went to the gate and called, " $\mathrm{O}$ daughters, $\mathrm{O}$ women, this is our day. To Awhitu, to Awhitu! And you, O men, you will not be able to act as my war party of women will do."

Sixty women in all passed through the gate and started towards One-hunga. Launching one of their biggest canoes, they paddled for Awhitu. As they neared the shore the mother of Puhi-huia stood up at the helm and said to those who had come out towards them, " $O$ you on that shore, put your war mats on and tighten your war belts, for we, the enemy, are here. If you hide yourselves, what can you gain? If you come and stand in view, what can you lose? Come out of your stockade. Why did you rob me of my daughter? What property have I of yours that you should take my precious greenstone and wear it on your breast? Come outside that we may fight our battle." 


\section{MAORIS OF NEW ZEALAND}

Puhi-huia again spoke: "I have already told you that you and I shall not meet in life, but if you persist we shall meet in the land of spirits. Why do you dare to blame this tribe when I the sole cause of your anger am here? Keep in your canoe, but let some of your female friends come on shore, that I may do battle with them, and if they kill me, then take my body home in your canoe. I will not be taken home alive by you, but will live with the one I love." Several of the young women came on shore, each with a war weapon in her hand. Puhihuia said to Ponga, standing near her, "Follow me and see me die." She said to the first of the warriors, "Here am I, the person for whom you have come." The young woman, holding in her hand a whalebone weapon, made a blow at the head of Puhi-huia, who parried the blow, then with the tongue end of her weapon dealt her antagonist such a blow in the pit of her stomach as to bend her double and bring her to the ground. Said our heroine, "Now another of you stand forth to meet me." One with a short spear made a thrust at her, but Puhi-huia parried the blow and hit her with such force on the shoulder as to destroy the power of her arm. A third female soldier attacked our heroine, but a blow in the pit of the stomach put her out of the fight. The fourth stepped forward with 


\section{MAORIS OF NEW ZEALAND}

a weapon which had no band to hold it to the wrist. It was hit by Puhi-huia with so violent a blow as to send it flying a considerable distance from her.

Then the mother of Puhi-huia cried out, " $O$ young woman, cease now. You have beaten them all; come back with me to your father." Puhi-huia said, "Will Kupe return?" This is the god who never ceases till he has gained the end at which he aimed. The mother said, "How shall I gain a place in the courtyard of your pah?" The old chief replied, "If you come by the authority of $\mathrm{Tu}$, the god of war, you must dare and make a road for yourself. If you come in the name of Tahu, the god of peace and plenty, I will make a way for you over the ditch of my stockade." The mother replied, "Have you seen the bravery of your granddaughter? Her ancestors were gods in war. She has inherited their power, she is not to be overcome. If the god of peace and plenty is her guide, what she undertakes she will accomplish. Stay here. I will return to my people, and when the moon is at the full I and my people will come to the feast given when she takes Ponga as her husband." Puhi-huia was standing listening to the words of her mother. As soon as her mother had ceased speaking she went and rubbed nosez with the young women whom she had beaten, who with her mother immediately set out for One-hunga. 


\section{THE FEAST AND THE WEDDING.}

THe Awhitu people now began to catch fish and dig fern and convolvulus roots, and, having dried them, put them into storehouses and on stages. Then they fished for shark and hung them to dry on long poles one above another. They also speared pigeons and preserved them in their own fat; collected cockles and cooked and dried them. Other shellfish also were caught and dried, and roots and bulbs which required cooking for a long time to make them palatable. A couple of days before the moon was full a messenger was sent to Mount Eden to invite the people of that place, to whom he said, "O people, you who live in this pah, for you all now is ready; on the day following to-morrow the feast will be laid in the courtyard of Awhitu. Come all, and welcome."

On the appointed day the Mount Eden people left Onehunga in their canoes. All came except the very old and decrepit. When they neared the landing-place at Awhitu all the people of that pah rose and waved their garments and sang their usual song of welcome:

Welcome, welcome, friends,

I bid you all a welcome,

My soul is weary

Of all cares of home. 


\section{MAORIS OF NEW ZEALAND}

My wonder is why

All the noisy crowd

So occupy their days

Beneath the shady trees.

But now I know

The tempting fern root, And the sweet Kauri stem,

Entice friends here.

Ye thousand stars above

Who twinkle over the

Highest bough of forest trees,

Pierce into darkest shade

of forest gloom,

And startle all the

Owls who dwell at

Our loved home, Awhitu.

Thus interesting all the land

And show with blaze of light,

The coveted new roots of fern.

The staff of life for man,

While on the ear he moves,

And let the new creation

Come where hands now toil

And feet are weary

With their walking.

Call ye, then, our babe,

Even heaven's own child,

Though skin of dusky hue,

When shall I be so

Charmed and follow

Close the progeny of him

They now call Ponga's child,

Which all the goblins say,

Is born of forest lizard. 


\section{MAORIS OF NEW ZEALAND}

Some of the Awhitu men and women went down from their pah to the beach below as those who are going to give battle, with their war paint, feathers and belts around their waists. There they waited for the crews to land, at whom they threw fern stalks and then ran back towards the pah, closely followed at full speed by the best runners of the Mount Eden people. As soon as those they had been pursuing were in the midst of their own people, the Awhitu tribes danced their war dance. Meanwhile, the guests had all followed up and were now drawn up in war array, kneeling on one knee, looking at their hosts. So soon as the Awhitu people had danced their war dance the visitors followed with one of theirs, and then all, hosts and visitors, joined in one great dance, led by the Awhitu people, all waving their garments. The Mount Eden people followed those of Awhitu into the pah and sat down in the courtyard. The visitors had not been there long when an Awhitu chief rose and made a speech of welcome.

He said things were better than they had seemed in days gone by. Then war was the rule on every, even little, provocation. He thought a feast was better than a fight, and a dance was to be desired rather than darts poisoned for destruction. The savory smell of roasted shark was more acceptable to all than roasted enemies slain in battle. The 
young people of Awhitu had been very diligent in search of the best the land yielded, and he hoped their visitors would find their meeting of the Awhitu people at the wedding a means of binding together in closer bonds the two great tribes which in earlier days had been the bitter enemies of each other.

A Mount Eden chief followed with an eloquent avowal that a sincere desire for peace between the tribes had very much more to do with their coming to Awhitu than the savory smell of the flesh of the shark or the luscious fibre of the sweet potato. They came also because of the invitation from the noble of birth who had chosen to change her home from Mount Eden to Awhitu. It was a grief to the Mount Eden people to lose one for whom they had so great admiration, but they were glad she was so near and still one of their great tribal family.

A chief of high rank of the Awhitu people, with a rod in his hand, stepped up to the heap of food and struck it with his rod, saying, "This food, this food is for all the tribes of the Mount Eden people in all their boundaries. The father of Puhi-huia then arose and with a rod touched one end of the food heap and said, "This food, this food is for all the people of the Awhitu tribes through all their boundaries." Then each tribe took their 


\section{MAORIS OF NEW ZEALAND}

own portion assigned them and ate it. When the feast ended, the head chief of Awhitu rose and went to the heap of those things counted of great value-as huia feathers, albatross down, mats, greenstone and other precious articles-and said, "These valuables, these valuables are for our ancestors who have gone to the world of spirits. These valuables, these valuables are for the priests and chiefs and for the family of my daughter Puhi-huia." These gifts were left in the courtyard until the evening, when they were distributed to the Mount Eden people.

After this the Mount Eden people went to their canoes and brought with them to the courtyard of their hosts dried codfish, dried mackerel and eels, preserved kiwi, cooked Maori dog, rats and preserved pigeons. A heap, also, was made of weapons of war and war garments and other costly articles. When the last of the tribe had added his contribution, the father of Puhihuia, standing near the heaps, said, "Hearken, O world of Darkness, and hearken, 0 world of Light, here are valuables for you; 0 ye gods and ye ancients and ye descendants of Hotu-nui, here is property for you; and you, my child, here is your property; and as you have left me I sorrow for you, I weep for you, but $\mathrm{O}$ my most 


\section{MAORIS OF NEW ZEALAND}

valuable property, as you must leave me, go, oh, go. If you had gone to death all would have been lost with you, but as this is but another canoe of our ancestors, and as we are also a canoe of the same, then go, yes, go, oh, go."

Though the old man's power to sing had long since ceased, yet his mind being clear and bright he repeated for the one now leaving, and for some of his who had gone to the spirit land, an old song often sung and repeated under similar conditions:

I silent sit as throbs my heart, Sighing for my children, All those who look on me, As now I bow my head, May deem me but a forest tree, From distant lands.

I bow my head as droops The weeping fern, And tears start for my children, Oh! my child, so often called, Come, oh! my child.

My house is swept, clean swept,

Clean swept forever, The shining sun has nought

To gladden now, And yonder peak oft

Gazed upon in days of joy 


\section{MAORIS OF NEW ZEALAND}

Now prompts the sigh,

To heave with chill

Of coldest air fresh

From the frosty south.

Oh, was it theft that makes

The moon to wane?

Or was it theft that makes

The mighty avalanche?

And was it they who

Caused my children's death?

The hosts of god uplift

Their power on us,

And now annihilate us,

Like the moa extinct.

When the old chief had ceased Puhi-huia arose and stood where she had been sitting at the side of Ponga, and said, "O my parents and grandparents, welcome, welcome! Come and see the one who ran away from you. Is the evil mine? Did I determine that Ti-ki should be a man ? Or that Kauataata should be a woman? No, this was done by the gods referred to in the speeches made by you. These gods were your progenitors. Is it wrong for me to follow in the steps of Kauataata? She is your progenitor and from her you take your sacredness, and from her you receive the gods who preside over you. She took one of her choice for a husband. If I am doing wrong, then your female ancestors did wrong also. If she had lived alone 
and kept to single life; none of you had ever seen the light of this world. The evil is not mine, it is your evil.

"When she saw the one she loved she recklessly pursued, and as your gods and you opened the path for such acts I followed in your footprints. This wrong of my leaving you is one of your own acts and was not of my planning. It is good that you have come to our feast. Now I say to you assembled here, and to all our tribes, that my husband, my husband, yes, my husband, is Ponga."

A more loyal Maori or more loving husband was never known among New Zealand natives than Ponga. Nor was there of them all a more devoted and loving wife than Puhi-huia. For nearly twenty years the life of husband and wife was one of uninterrupted peace, contentment and prosperity.

One son was born to them. He was called a tau-tihi, because he had neither a predecessor nor successor-what we would call an only child.

When he had very nearly arrived at manhood and har been tattooed, news came that one of the tribes of their great nation, who had gone to Wai-ta-ra to buy garments in exchange for their own local products, had been murdered and eaten.

One hundred warriors collected immediately at Wai-uku, 


\section{MAORIS OF NEW ZEALAND}

and from thence set out to avenge the murder of their relatives. Fifty more left their home at Awhitu and went up the Wai-ka-to river, where they were joined by fifty more of their people, all bent on severely punishing those who had so offended and wronged their nation.

The first hundred, after killing some of the murderers and their friends at Pu-ke-aruhe, and many more in the surrounding district, returned home. The second hundred, who went by way of the Wai-ka-to, and then on to Mokau, and thence on to Maro-kopa, were never heard of again by their friends at Awhitu. Whatever befell them no Maori knows to this day. All traces of them were lost forever. Ponga was one of these.

After many moons, when no tidings could be had of her beloved, Puhi-huia set out with her son to seek their lost one. Before her departure she sang this mournful song of lament for him whom she loved more than her life:

How grand the mountain Piki-horo looks. How shall I

Weep and tell my sorrow

For thee, oh, my beloved !

Keen sorrow, day and night, And pain of lacerated Flesh, my trembling Frame o'erpowers. 


\section{MAORIS OF NEW ZEALAND}

Oh, would some priest

Enchantments bring,

And in the stream

Revive my soul.

I know, oh, yes, I know

The house where Tatan dwelt,

And where the Mae-waho,

In crowds, all met their doom.

And slept in death, and

Where the Pona-turi's voice

Was hushed to speak no more.

So I for thee will mourn, beloved.

The sorrowing Puhi-huia and her son, hoping against hope that they might yet get some tidings of him whom in vain they sought, went up the Wai-ka-to river, and there, with friends, remained for some weeks; thence to Mokau, where they stayed for a few months, soliciting tidings from all who came down the river. They then proceeded to Kawhia and tarried there several days, and then up the Kawhia river and through the mountains of that region.

Through these long journeys, sometimes at the homes of their friends, whose hearts were full of sympathy for them in their patient quest: sometimes lodging in the caves of the mountains or under the broad fronds of the palm fern, Puhi-huia imparted to her son, in whom was all her hope if their search should fail, many of those songs and legends and historic events of her fathers, from the ancients down 
to her own times. Being the daughter of the highest of all the chiefs of her people, she was by birth the noblest Maori of them all. She had, therefore, had opportunities to learn these things, such as the more common people of her nation had not enjoyed.

What more could she do than was done by the mother of the great Hebrew lawgiver-pass on to her son a correct knowledge of all the history, religious beliefs and poetical productions of her people, that he might hand them down to those coming after him?

Each mother taught according to her light. What could she do more? And the light which fell upon the earlier maternal instructor, we may discover, imparted also some of its rays, even though very faint, to the mind of the later teacher.

A record of Puhi-huia's talks with her son may not be of so much value to us as the conversations of Jochebed, the wife of Amram, with hers, yet when we find that in some degree they really are related and similar, so that the threads of Puhi-huia's teachings, though rotten threads, perhaps, are, after all, from the same texture as that woven by the mother of the great lawgiver, the subject before us becomes more interesting.

The heathen are not altogether dark, as in earlier days 


\section{MAORIS OF NEW ZEALAND}

they have been supposed to be. There are, here and there, thoughts which Christian men may respect. These better thoughts, rising far above the bulk of their beliefs and superstitions, are simply scattered rays, perhaps piercing the clouds above them, yet rays from that infinite Sun which enlightens us all.

Aside from this, we shall learn something of the thoughts of our brethren who have lacked our opportunities and advantages. We shall learn something of men who had nothing in common with ourselves except that they were men. When I say " nothing," I mean, of course, our civilization. The question has been sometimes very reasonably asked, What, after all, is civilization? And according to our standards of civilization, is it an advantage? While that condition we designate as such certainly does deliver us from some forms of evil, it seems to burden us with other forms of evil. In some respects it is terribly and painfully overdone. The conventionalities of society often burden us with chains from which anyone loving true freedom is glad to escape.

Happy is that one who is content with the simpler lifelife among the lowly.

"Oh, but these Maoris used to eat their fellow creatures, especially in times of war." 
Not until after their fellow creatures were dead, and then only slain enemies. Paul seemed to think that there were some to whom he found it necessary to say, "If ye bite and devour one another, take heed that ye be not consumed one of another."

I fancy the biting and devouring to which the Apostle had reference is not a very great improvement upon the cannibal consumption of a slain and roasted enemy. I don't commend either the one or the other, but what is the use of blinking at it? It is worse. Many a poor, honest, yet nervous and sensitive soul has been done to the death by the gossipy and slanderous tongues of empty-headed and Christless-minded members of the Church, who, while they professed to be followers of a meek and loving Master, were cannibals of the lowest degree.

By way of preface to his warning Paul gives us the only basis upon which a true civilization can be founded and built up, namely, "Thou shalt love thy neighbor as thyself." If we rise to this standard we shall bite and devour our neighbors neither with our teeth nor with our tongue.

I said, some distance back, that there were some reasons for thinking their ancestors came to New Zealand from the Sandwich Islands, although that cannot be established for a certainty. 


\section{MAORIS OF NEW ZEALAND}

Assuming that to be a fact, we can easily account for some of their religious ideas being quite in harmony with those great truths taught by Moses. It must be that the Sandwich Islanders from the very beginning of their history knew something of the teachings of our own great inspired lawgiver, though how they came by that knowledge will ever remain a mystery to men.

I spent three very pleasant weeks at Honolulu, my home while there being at the residence of the Rev. Dr. Beckwith, pastor of the Congregational Church. I found in his library a work consisting of three volumes written by "A. Fornander," who was for thirty-four years an official of the Hawaiian Government. He had a native wife. He was for several years Circuit Judge of Maui.

I could not persuade the Doctor to sell me the work. I wrote my son in London, who visited ten of the largest second-hand book stores, but he could not secure me a copy. Fortunately I took some notes, though I regret I did not possess myself of a larger supply.

I give the reader the benefit of the notes I have. I have already said that they had a system of refuge cities and traditions of the flood, with Nui (Noah) as the chief personage. The ancient Hawaiians worshipped one god, who in himself embraced three beings, equal in nature but 


\section{MAORIS OF NEW ZEALAND}

distinct in attributes. The first was, however, considered greater than the other two.

These gods were Ka-ne, $\mathrm{Ku}$ and Lono. These existed from all eternity.

By an act of their will they broke Chaos in pieces that Light might enter into space.

They then created the heavens, three in number, as their dwelling place, and the earth to be their footstool.

Next they created the sun, moon and stars and angels.

Last of all they created man, a model after the image of Ka-ne.

The body of the first man was made of red earth. His head was made of whitish clay which was brought from the four ends of the world.

When the earth image of Ka-ne was finished, the three gods breathed into its nose and called on it to rise, and it became a living being.

Afterwards the first woman was made from one of the ribs of the man when he was asleep.

These two are called in Polynesian chants and legends by a great variety of names, the most common being, for the man, "Ku-mu-honua," and, for the woman, "Ke-olaku-honua."

Getting away from the Hawaiian group, where these 
things were taught, many hundreds of miles farther south, and after very many, many moons, with no written language, it is not wonderful that other ideas had crept into the minds of the natives of other islands in the southern seas.

The people in some of the Polynesian group had a tradition which related that in the beginning there was no life, light or sound.

A boundless night enveloped everything over which the god Tanaoa (darkness) and the god Mutu-hei (silence) ruled supreme.

The god Atea (light) separated himself from Tanaoa (darkness), made war on him, drove him away and confined him within limits.

The earth, they say, was fished up out of the sea by Tanaoa. Some of them claim that man was a direct creation of Tanaoa, who made him out of red clay, and then made woman out of one of his bones; hence she was called "iwi," that is, a bone.

The Hawaiians said that the home of the first pair was a beautiful land, a very sacred land. The man, they said, must have been very holy who could dwell there. They sang of it in their chants.

According to their tradition, a beautiful river ran 


\section{MAORIS OF NEW ZEALAND}

through this land. Its banks were very splendid. Its waters had such life-giving properties that if a man who had been killed were sprinkled with it he would come to life again.

In this wonderful land there grew a tree called the ulukapu-a-kane, or the tabooed or forbidden bread-fruit of the god. Here is part of a chant referring to the trouble which came to man from having eaten of this tabooed fruit. While the result, according to the sentiment of the chant, tallies well with the account given by Moses, the chant seems to make that account more emphatic.

Oh! Kane, Laao, uli, uli, uli!

Oh! fallen chief, dead by the

Feast. Dead by the oath,

Dead by the law.

Oh, vanish the stars,

$\mathrm{Oh}$, vanish the light,

In company with

The blushing moon.

Cursed be my hand,

Cut off through my cause.

I am dead by the law,

Yes, indeed, truly.

Oh! Kane, Laao, uli, uli!

To the gods disobedient.

May you speedily returr.

Again to the dust. 


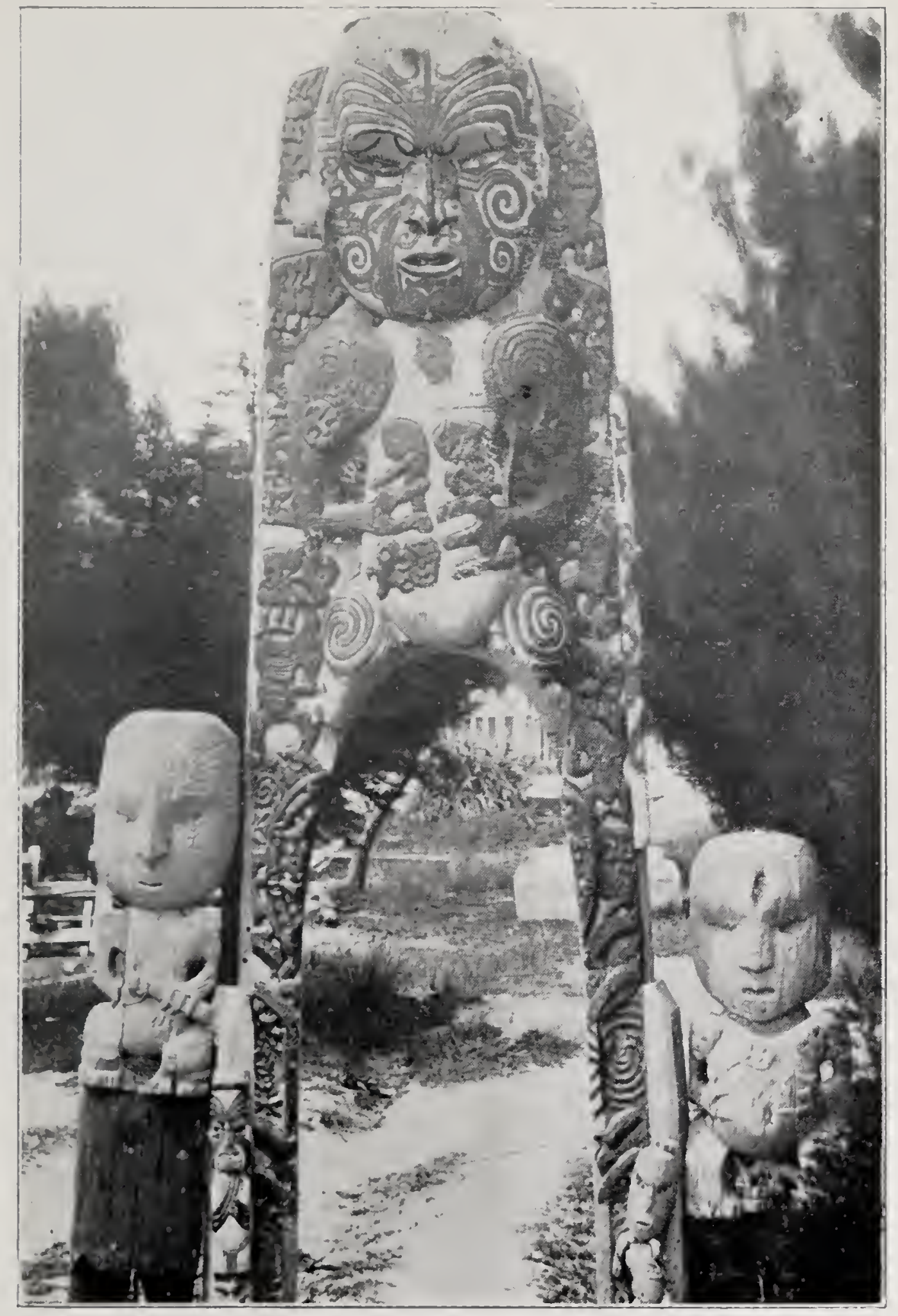

FNTRANCE TO A CEMETERY 

The deluge was caused by two bad grandsons of the god killing a favorite bird. When he remonstrated with them they added insolent language to their wrong-doing.

To punish them, he gathered the clouds, which burst over them. Towns, villages, mountains and plains were all submerged. The rebels cried to a god, who instructed them how to make a big canoe, by which eight persons were saved. Among all these South Sea peoples are many versions of the story of the great flood. Not all of them give the name of the principal actor. One of these versions, however, gives this person the name Nui (Noah), as briefly stated in a preceding page. He, by command of his god, made a large boat (" the royal vessel"), by which he and his wife and his three sons and their wives were, saved.

When the flood subsided, the three gods, Ka-ne, Ku and Lono, entered the royal vessel and commanded him to go forth, which he did. He found himself on the top of a very high mountain, where for a time he dwelt in a cave with his family. He named the cave after his wife, and there it is to this day to assure you that this tale is true.

When Nui came from the royal vessel he took a pig and some cocoanuts to offer as a sacrifice to Ka-ne, the chief deity. As he worshipped, looking up he saw the moon. 


\section{MAORIS OF NEW ZEALAND}

He said, "No doubt you are Ka-ne," and so he offered his sacrifice to the moon.

The god descended on the rainbow and rebuked him, but as Nui had done it ignorantly and at once had asked forgiveness, he was forgiven, and the god reascended to heaven, leaving behind him the rainbow as a sign or token of his mercy.

Stones, partly dressed, about six feet high, are common emblems of worship, and if near a dwelling are significant of family, worship.

At Roto-rua, in New Zealand, I saw one of these sacred stones, which was said to have been lost for many years and its loss greatly lamented, but it was rediscovered on ground where a great battle had been fought.

It was locked up in a small, well-built house, about the size of a sentry-box. The tribe professed that the key could not be found. A fellow tourist and I succeeded, however, by prying up an unfastened window, in getting a glimpse of this celebrated stone, in the estimation of the Maoris one of the most sacred relics of their past history.

I have dwelt longer on the beliefs of the more northern groups of the Islands of the Pacific, because of the more definite doctrines of the Polynesians, and because the writer from whom I have taken these definite statements has with 


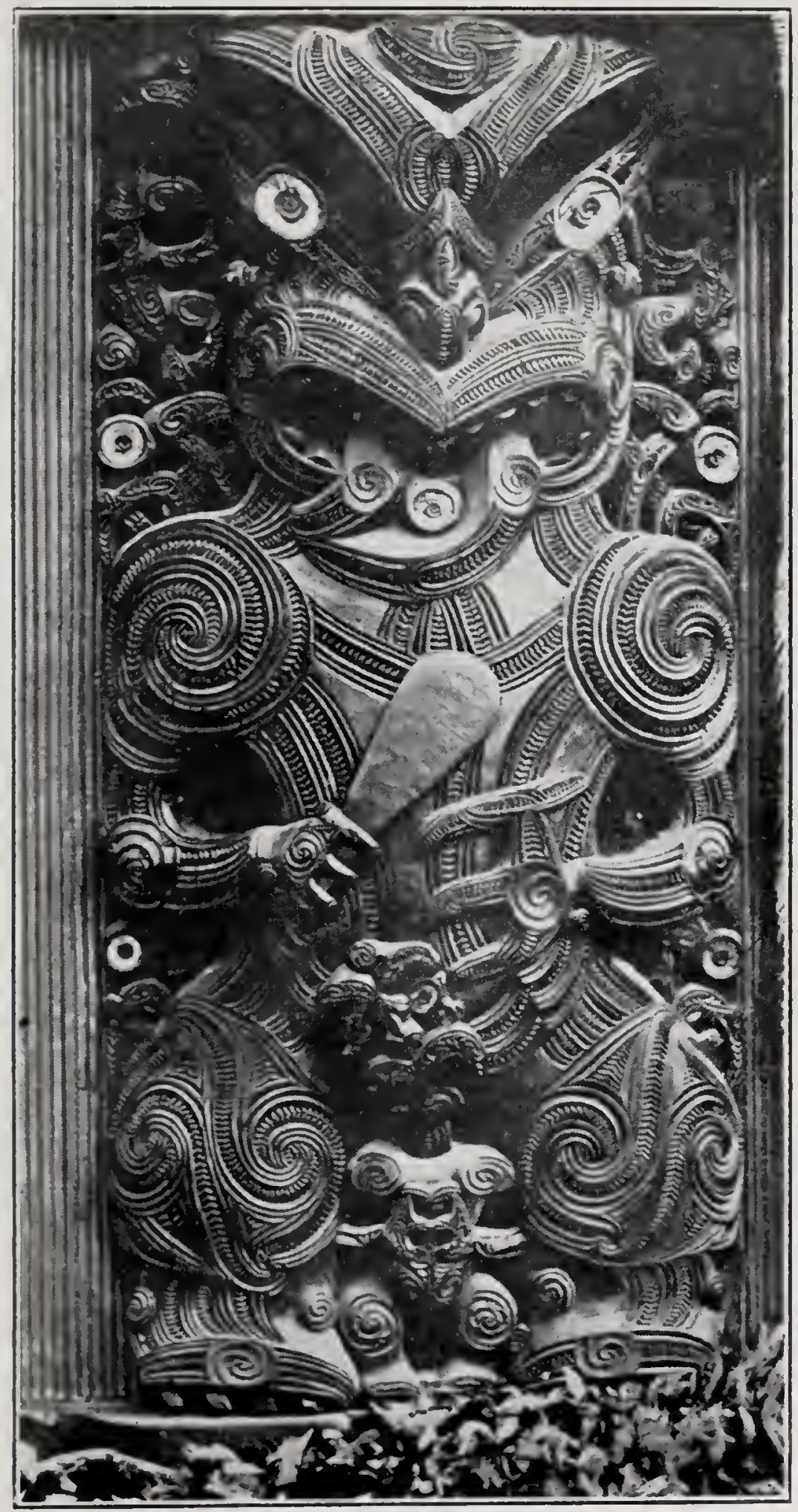

MAORI WOOI) CARVING 
such great research made himself so familiar, and has with great credit to himself given us such interesting and valuable information.

I repeat, where, when or how all these people, so far removed from the centres of our civilization and intelligence, obtained their ideas, so fully in harmony with our own ideas respecting the origin and early history of our race, must, I presume, ever remain a mystery.

With the Maoris, Ta-ne (not Ka-ne) is God. Rangi is heaven, Pa-pa is earth. The first man was Ti-ki (tee-kee), and Mariko was the first woman.

When their first child was born clouds began to skim over the sky. There were dark clouds, black clouds, and very black clouds.

Water began to flow, and the banks of rivers were seen and dry land was preserved from floods.

Then was the earth seen in the dawn of day. There was lightning and thunder. Then came rivulets and streams flowing on to the rivers.

Then was seen the full light of day, and Ta-ne propped the heavens up and great Rangi was seen above. Then light and day were complete.

To Ta-ne belongs the taboo (prohibited) of everything sacred. 
This is the chant of Ta-ne relating to the creation of man :

Seeking most earnestly, Seeking in the gloom, Searching. Searching on The bounds of light and day, Looking into night, for Night had conceived

The seed of night, the heart. The foundation of night Had stood forth self-existing, Even in the gloom.

It grows in gloom like sap And succulent parts of life, And the pulsating cup of life, The shadows screen the Faintest gleam of light, The procreating power and Ecstasy of life of man first known And joy of issuing forth of man, From deep silence into sound.

Thus the progeny of man From Tane the great extending, Filled the heaven's expanse. The charms of life created Arose and swelled in ecstasy, Then rested long in bliss Of happy calm and quiet.

There were many chiefs and priests when men had grown numerous upon the earth. 


\section{MAORIS OF NEW ZEALAND}

Rua-tai-ao (ti-ow) preached the words of life to the greater portion of the people, but many were disobedient.

Wi, another good priest, taught the people all the laws of Ta-ne, having derived his power and wisdom from Ta-ne. He said, " $\mathrm{O}$ friends, hearken to the words by which we may be saved. Live peaceably. Do not work evil. Do not be disobedient. Do not be intemperate. Do not offer false, lying worship, but let your worship be true.

These people and their leaders resisted.

Wi spoke to $\mathrm{Wa}$ and Miru, and said, "O young people, you two, hearken to my words which I now utter. When you eat, give thanks. Educate and build up the soul, that it may go correctly to the world of spirits. Believe what I now tell you, as this is the truth of Ta-ne."

They did not hearken. Wi thus preached for two years to this unbelieving people.

He then called to them and said, "Soon, on the morrow, the land will be overturned by God." So when the days were ended, he prayed to Ta-ne, and the land was overturned and all those wicked people perished.

Puta was another of the priests who preached to the people in those days. He built a temple in which to teach men how to become noble.

They were rebellious and said, "O Puta, can your wor- 


\section{MAORIS OF NEW ZEALAND}

ship save you?" Puta replied, "Hearken, O friends, to the words I now disclose to you. They are the words of Ta-ne. If you hearken not, soon the hosts above will make accusation."

The proud people answered, "Friend, your words are lies." Men had then become very numerous upon the earth. There were a great many tribes. Evil prevailed everywhere. Men obstinately opposed the teachings of these good priests and declared them to be false, and asserted that Rangi and Pa-pa, heaven and earth, were as they had been from the first, and that Ta-ne had not done and would not do as they taught.

Then Tupu-nui-a-uta and Para-mea got stone axes and cut down totara trees and other light timbers and dragged them to the mouth of the river To-hing-a. They bound the timbers together with vines of the pirata and made a very wide raft.

Then they repeated an incantation prayer and built a house on the raft and put much food into it, and then they prayed that rain might come in such abundance as would convince men of the power of Ta-ne and prove the truth of his existence and the necessity of worship for life and peace.

The priest on the raft prayed that it might rain in great torrents. 


\section{MAORIS OF NEW ZEALAND}

On the next day the rain had reached the settlements. All men and women were drowned of those who had denied the doctrines of Ta-ne.

The raft floated down to the sea and for many days went hither and thither till at length it reached the land again.

Those on the raft thought that some of the people of the world might perhaps still be alive and that the earth might still have the same appearance as it had before the flood. They saw, however, when they had landed, that not one of all human beings remained except themselves, and that the earth was greatly changed. It had cracked in places and had evidently been turned upside down.

When they landed they repeated incantations to all the gods and offered sacrifice of seaweed.

After this, the high priest, with a branch of a tree in his hand, went to the edge of the water, and, dipping the branch into it, he turned and faced the people and waved his hand towards them and threw the water in their direction. This he did three times. Then, returning to his people, he sat down by a fire produced by friction in which to cook fern root as an offering to the gods for the company rescued from the flood. They sat until the fire had all gone out and the sun had set on the first day of 


\section{MAORIS OF NEW ZEALAND}

their restoration. In joy they produced fire by friction and cooked food and ate it and slept.

On the morrow, when they had eaten their morning meal, they looked up and there they saw the rainbow in the sky.

Raki, one of the gods, said to Ta-ne and to his younger brothers, "Come and kill me that men may live."

Ta-ne said, "How: shall we kill you ?"

Raki answered, "Lift me up above, that I may stand separate, that light may come upon you all. If I die, then light and day will be in the world."

Ta-whaki, another of the gods, at one time lived in the earth, and, though a god, he had the appearance of a man. His garments were like those of a poor man.

He went up to the top of a mountain and sat down. Then he put off his earthly garments and clothed himself with lightning. From thence all the people looked on him as god and all the tribes chanted incantations and offered sacrifice to him.

Ta-whaki was killed by some of his own relations, but he was innocent of the deed for which he was killed. By his own inherent power he came to life again. He climbed, by means of a spider's web, into heaven, into all the various heavens, chanting incantations as he went. There he learned the incantations which are there taught, and then 


\section{MAORIS OF NEW ZEALAND}

returned to earth and taught them to men. He then returned to heaven and there remained.

I have picked out the foregoing from very much that they have themselves invented, and which therefore would be of small interest to the reader, who, I think, will feel with me that the Maoris at some perhaps very early date had not only heard the story of creation as told in Genesis, but also the story of redemption as it is told us in the New Testament.

Here is a very ancient lament said to have been taught to men by the god Ta-whaki, who, as I have just shown, died an innocent victim for men:

Bow to earth and bow to

Heaven. Wilt thou, 0 man?

With craving hunger driven,

Weary, gaunt and near insanity,

Must wander, aimless and alone,

While death creeps nearer still,

And to one focus draws

Thy path of glory.

Honor, fame and joy

Which youth laid out

But blots and blurs

The whole, whilst staggering

Thou canst scarcely sweep

The grass aside that grows

Along the path that leads

Up to thy home in heaven. 


\section{MAORIS OF NEW ZEALAND}

How cowed and servile Gnawing hunger makes The soulless frame to stagger, When at low eventide The reeling form oft seeks To eat the refuse cockles Cooked and left by others.

How crushed by shame Once noble self now dies Within, as crouching, Thou drawest near, To see thy boyhood's home.

No welcome greets by Uttered words, or calls Aloud thy name.

But thou must onward pass, And in the path of famine, Up to the gate of heaven, Go, where though a starved One, thou mayest hear The welcome word That bids thee come.

From their folklore I cull some of their legends, which generally are so absurd the reader would not find much interest in them. Two or three of them, however, may be acceptable and serve as fairly good specimens of the whole. 


\section{MAORIS OF NEW ZEALAND}

The Legend of Toi and Tama.

A dog of Tama had eaten something which Toi had intended for his own dinner, so what should Toi do but eat the dog, after he had killed and cooked him.

Tama went hunting for his dog, calling louder and louder, till at last the dog howled " $\mathrm{Ow}$, ow," in the stomach of Toi. Tama and his brother went on calling again and again, and the dog kept answering "Ow, ow." Then Toi held his mouth tight shut, just as close as ever he could, putting his hand over it, but the dog kept howling, " $\mathrm{Ow}$, ow."

Toi said, "Oh, hush, hush! I thought I had hid you in the big stomach of Toi, but there you are, howling away, you cursed thing."

When Tama and his brother had located the dog, Tama said to Toi, who was his relative, "Why did you not kill the dog and bring it back to me, that my heart might have felt satisfied?" But Toi said, "Yes, but if I had not eaten the dog, when he had eaten my dinner, my stomach would not have felt satisfied."

We can come a little nearer home to get stories from some of our own ancestors not a whit better than this:

In Caxton's life of St. Patrick we are told that, "it 


\section{MAORIS OF NEW ZEALAND}

happed on a time that a man of that contre (Ireland) stole a shepe which belonged to a neighbor, whereupon St. Patrick admonished the people that the shepe must be restored. The man that had stolen the shepe made no sign, whereupon St. Patrick commanded by the virtue of God that the shepe should blete and crye in the belly of him that had eaten it; and so happed it that in the presence of all the people, the shepe cryed and bleted in the belly of him that stole it; and the man that was culpable repented him of his tresspace and others thenne forthe were kept from stelying of shepe from any other man."

\section{The Legend of Maui (mow-ee).}

Maui went on a fishing excursion with his brother-inlaw, Ira-waru. Maui caught no fish, for his hook had no barbs. He expressed surprise that his companion should catch so many and he none.

Their lines became entangled and both felt the fish jerking. Maui said, "Let me pull the lines to me, as the fish is on my hook." The other said, "Not so. The fish is on my hook."

Maui said, "Let me pull my line in, then."

Ira-waru did so, and then saw that the fish was on his hook. 


\section{MAORIS OF NEW ZEALAND}

He said, "Untwist the lines and let mine go, that I may pull the fish in."

Maui was so enraged that when they reached the shore he sprang upon Ira-waru, knocked him down, trod on him, pulled his backbone out long and turned him into a dog. On reaching home, his sister said, "Where is my husband?"

He replied, "He wished me to say that you were to go and bring his fish. If you do not see him, if he does not come, call for him as you would call for a dog." She went, but not seeing her husband, she called aloud for him. When he did not come she called, "Moi, moi, mo-i-i-i."

Ira-waru heard the voice of his wife and came towards her, wagging his tail. She was quite shocked and overcome by the appearance of her husband, and returned home weeping, followed by her husband.

She took a girdle and apron to bind around her, that she might go to the sea and drown herself and be eaten by the monsters of the deep. Having arrived at the seacoast, she is credited with having composed the following song.

Of course, the story is a mere idle legend, with no foundation in fact, yet the song is there. It must have been the offspring of some Maori bard, and counted among a thousand such, collected by Sir George Gray, who spent so many years among them, without any written language or books 


\section{MAORIS OF NEW ZEALAND}

to aid him to master their tongue and possess himself of the wonderful literary productions of these very extraordinary people.

I weep, I call to

The steep billows of

The sea. To him the

Great, the ocean god,

To monsters all,

Now hidden there,

And all the seals, to

Come and me entomb.

To me, who now am

Wrapped in the mourning garb,

And let the waves

Wear mourning, too.

There let me sleep,

As sleeps the dead.

I weep, I call to monster

Shells of ocean deep,

And thou great wave

Of endless roar, to

Come and me engulf,

Yes, me, who calling now,

Implore a mighty host

To come and gratify

My ardent wish.

Oh! let the heavens wear

Their mourning garb,

And let me sleep

The sleep of death. 


\section{MAORIS OF NEW ZEALAND}

The absurd legend goes on to say that she threw herself into the sea, but after many moons her body drifted ashore, where it was found by two brothers.

When they saw how beautiful she was they rubbed the moss and seaweed from her face and placed her close by the fire, and soon she came to life again.

When asked her name, she gave them a new name which meant that she was a child of the ocean.

Tine-rau (tiny-row) took her to his home for his wife, but he had two wives already, who kicked up something more than a tiny row on seeing this new and handsome arrival, so they cursed her and tried to kill her.

She was so grieved at their conduct that she determined to bewitch them, and for this purpose she chanted the following incantation: ( $I$ give a few lines of it in Maori, as it may be interesting to the reader.)

\begin{abstract}
Haruru to toki
Nga hoa ta toki

Hei paoitto

Uru to toki

Tena toki ka

Haruru tena

Toki ka ngatoro

Ko te toki o

Whiro te tupua

Manawa ko koe

Kai tangata.
\end{abstract}


Let the booming

Blows of the axe be

Heard, and pain the head

With deafening din.

The axe? O yes, the axe,

To smite your head,

The axe to scatter

All your brains.

Oh! now the blows

Of the axe are heard.

The chips are seen,

Scattered far and wide,

Yes, the great axe of Whiro,

The monster and avenger,

The great man eater.

No sooner was the charm repeated (so Maoris say) than the heels of the jealous rivals were seen in the air and their bodies were stretched lifeless upon the ground, and the mermaid had her new husband all to herself.

The following song is accredited to the wife of a chieftain who was slain in one of their great battles:

How cold and dim it is

Within the house, for thou, My love, art to a distance gone,

And I must wait the throng,

If out on ocean far

What shall I see?

Shall keen regret

Thy soul then tightly hold? 
Ah! no, I feel that thou

Art one of those from

Whom come with daring

Thoughts of war.

But what can be the

Deadly pain I feel

Now throbbing in my heart

That burns as fire within.

I dread the future now,

Yet all will be forgotten

In the depths of darkest gloom,

Oh! come back to thy wife,

Nor let her feel and dread

The awe oft felt by those

Who wait the coming of the foe

To make them slaves.

Oh! Te-pa-ea, where wast

Thou then when my bright

Days were young?

We loved each other

Then, as others loved.

But though cast down,

And left as wrecked canoe,

I shall not be destroyed,

But I shall still, like

The canoe, be strong again,

And by the ocean wind

Glide o'er its rippling waves

Where often calm is felt.

Another fallen chieftain's wife sang her mournful dirge for her dead beloved. Surely, how like ourselves these poor 


\section{MAORIS OF NEW ZEALAND}

people are. They, too, have hearts that feel life's burdens and life's woes. What a blessed Gospel is ours for all our race. It only can bring comfort.
Ah, wind! now passing to
The north, blow, blow gently
On my path, but onward go,
Go first and I will follow,
Will follow thee.
Lead, that we may onward
Go by this path to the
World of spirits. Ah, me! to
That world and isles
Where life is great.
Where I may see, ah, me!
Where I may see but him,
Ah me!

The following story will show the ingenuity of a tactical warrior :

When a battle was apparently imminent, a principal chief commanding the expedition on the one side, greatly fearing, as the two forces drew quite near to each other, that the opposing force was very much stronger than his own, said to his followers, "O people, light fires at some little distance from each other. Let them be large. Let three women be at each fire with some of you men, and let each man make a speech, and let a man at each fire speak, and 
speak at the same time, and let all say, 'Be brave to fight on the morrow, $\mathrm{O}$ sons, when we are attacked by our enemy. Do not think of life." "

The men thus directed did as their chief suggested, and as they used their voices the sound was loud and strong, like a great trumpet uttering a war call which might be heard far off.

So thus these warriors spoke, and brave were their throats to utter such speeches as they made. These great, loudsounding speeches, being heard by the enemy, made them think that an immense army was encamped just in front of them, and they fled back to their country, and their fear was so great that they never returned to attack their wily opponent.

It is a mistake to suppose that the condition of Maori life was one of privation, suffering and gloom in times of peace. On the contrary, it was rather a pleasant life. There was usually an abundance and a variety of food.

There was also agreeable and healthy occupation both for mind and body. Each season of the year and each part of the day had its specially allotted work both for men and women.

The women, in addition to such household duties as cook- 


\section{MAORIS OF NEW ZEALAND}

ing and cleaning their houses, made the bedding and clothing required for their families. They gathered the wild flax and prepared its fibre for use, and worked it up into a great variety of articles both useful and ornamental, many of which required several months to complete.

The men gathered the food and stored it in "whata," or storehouses built upon tall posts to protect it from damp and rats. One of these "whata" was owned by every family.

Besides such natural products of the soil as fern root, stems of the tui-palm, and convolvulus roots, they cultivated the kumura or sweet potato, tara and karaka.

Fish were caught in the proper season and prepared for storage by drying. Wild pigeons, kaka (parrots), ducks and titi (mutton birds) were cooked and preserved in their own fat, in vessels made of large kelp leaves and bound round with totora bark to give them strength.

Netting, carving, grinding by friction, and fitting stone implements and weapons occupied the time of the old men and a good deal of the time of the young men as well.

I visited several of these "pahs," or villages, during my stay of nearly a year in New Zealand, and have in my possession a goodly number of specimens of articles such as they manufacture at their homes. 
I visited one pah in the hot lake district where they need no fire of any kind, cooking being done by means of the boiling hot water which comes bubbling to the surface from the depths below. Over a hole a foot or so in diameter they hang a dressed pig in a packing case, got from the white village near by, and cook him thoroughly in a couple of hours or so. The women, with dippers with long handles, lifted boiling water out of the earth for washing, or making tea.

They beguile the winter evenings by tales of myths, historical traditions, tribal genealogies, chanting and singing poetry, by telling fairy tales, or performing the haki-haki games or the hari-hari war dances.

It was only when they were ill or were harassed by their enemies in times of war that the ancient Maori could be said, with any truth, to be unhappy. Even in war, the ablebodied men delighted in it, so here also, among this class of Maori, there was no real unhappiness, especially for the victor, though woe unto the unhappy ones who proved the weaker party in the fight. Roasted! eaten! and their smaller bones worked into needles and fish-hooks.

Some poor poet, finding himself going to the wall with all his tribe in one of their conflicts, sings thus: 
Overcome and exhausted,

I am in spirit, dead.

Oh, that the war girdle

Might expand itself

And flaunt itself,

For me. Yes, for me.

I cry trembling,

I wail, oh, me!

And my calamity on

The mountain of life

In the midst of power

Of bitterest foes.

$\mathrm{Tu}$, come near to Maru,

And Maru come near

To Rongo, and you,

o Rongo, come near to me,

Come near to my calamity.

The reader will be interested in some of the stories and legends they used to tell each other when sitting around their fires. Some of them were of things above, like a few of those of their religious beliefs already narrated in the earlier part of the book, and some of them may be classed with our own fairy tales.

Ta-ne and Rangi, his father, dwelt in the upper worlds with their spirit hosts. Of these hosts some of the leading spirits persisted in trying to draw many of the others into rebellion. Orders were therefore given to expel them, and 
Ta-ne, who had the power to do so, cast them out, and they fell down from the first heaven.

When they had fallen to the earth they set about securing the destruction of those creatures Ta-ne had made and placed upon the earth, and thus be avenged for their having been cast out of heaven.

There was a second and also a third rebellion in heaven, in which thousands were killed, that is, so far as it is possible to kill spirits. Ta-ne was determined to kill all, but the god Raki proposed that the universe should be divided and that the heavens should be altogether separated from the earth, so that these spirits might become human by assuming bodies. To this Ta-ne would not agree. Because of this, these spirits were doomed to stay in darkness.

This was the result of their rebellion. These rebels were driven from the upper heavens, and their unalterable fate was to live in doubt in this world and in the world of darkness beyond this world.

Some of the priests say it was $\mathrm{Tu}$ and Rongo who first made war and killed men, but the beings killed were not like men as they are now. They were gods.

Rau-riki was the first to kill man in this world. He killed Hotua, because of jealousy. The females loved 


\section{MAORIS OF NEW ZEALAND}

Hotua and praised him for his nobility and beauty. When the news of his death reached his relatives they sought satisfaction.

They dipped the forefinger of their left hands in the blood of Hotua, and held their hands up towards heaven, and then they pointed downwards. This they did many times, all the while repeating their incantations and naming each god in heaven and all the names of heroes above and below. Then they repeated the incantations of "Life and the origin of all things":

Peal thou thunder in the sky That I may hear thy booming, Like to that of rushing tide, Cast down the prop of life That gods above and gods below May hear the words of Apa-Kuru.

Now she utters words of dread, of lonely desolation;

And laughs the laugh of madness, To her own kindred blood, And begs for retribution For the death of Whaka-rara.

His sister wails in agony Of woe upon the ocean shore.

She calls the sacred hills

To smite the soul of him

Who did the murderous deed.

Now to her aid comes Nuku. 
As darts the flash of keen

Revenge from out the

Eye of endless spite,

The hosts of Kewa come,

Assembled in the clan of

Those who would

Her cause espouse.

This was all done when the army went to avenge the death of Hotu-a. When the fight was over, the victors took the first prisoner captured, and, after killing him, presented his heart to the high priest. This he cooked and ate. They then killed all the other prisoners, carefully saving all the blood, which they offered in sacrifice to the gods. Then the bodies of all the slain were cut up and cooked and eaten by the army.

This was the origin of cannibalism in this world, and the practice has been continued down to the present time.

After Ta-ne had arranged the stars, and made his father, Rangi (heaven) beautiful, and formulated the laws of taboo, he visited the earth and then returned to the heavens above.

After his departure the spirits of the lower worlds sought to be avenged on Ta-ne for the part he had taken in driving them out of heaven.

They first caused evil amongst the fish of the sea, and multitudes of them were destroyed. 


\section{MAORIS OF NEW ZEALAND}

They then caused evil amongst the birds of the air, and great flocks of them perished. And when men were multiplied they caused evil amongst them.

\section{The Story of Rata.}

When Rata's father was killed, he determined to avenge his father's death. For this purpose he went into the forest and having selected a tall, straight tree he felled it and cut off its beautiful top, intending to fashion it into a canoe on the morrow.

When the insects who inhabit trees and all the spirits of the forest learned what Rata had done, they assembled during the night and, while singing aloud their incantations, put the tree back into its place with every chip and shaving and branch, just where they were before.

This is what they sang, with the confused noise of various voices:

Fly together, chips and shavings,

Stick ye now all fast together,

Hold ye firm and fast together.

Stand thou again, O tree, upright:

Be our monarch of the forest.

Early the next morning back came Rata to hew the tree into shape for his canoe, when lo! where is the tree?

If that tall, straight tree standing there is not the one he felled, then his eyes greatly deceived him. 


\section{MAORIS OF NEW ZEALAND}

However, Rata thought it was useless to waste time wondering, so he at it and felled it again.

When he went to his home at nightfall the insects and fairies and imps of the forest returned and set it up again.

When he returned the second day, lo! there was the tree erect.

Nothing daunted, he felled the tree once more, and then started off as if going home, but when he had gone a little way he hid himself in some thick scrub.

He very soon saw an innumerable multitude of the spirits of the forest approaching the tree, singing their incantations as they came along.

When they had arrived at the fallen tree and were about to raise it again, Rata rushed out upon them, saying, " Ha! ha! then it is you, is it, who have been exercising your magical arts upon my tree?"

Then they all cried out, "Who gave you authority to fell our forest god to the ground? You had no right to do so."

Rata was very much ashamed and quite sorry for what he had done.

They said, "Return, Rata, to your home. We will make a canoe for you."

They were so numerous and so familiar with the forest 


\section{MAORIS OF NEW ZEALAND}

that they were not long in making a canoe for Rata capable of carrying 140 men, all warriors, who embarked with Rata to seek his father's bones.

One night, a week or so later, they reached the fortress of their enemies. Rata alone landed, leaving all his warriors on board.

As he stole along the shore he saw a fire burning on the sacred place, and some priests near the fire performing their incantations.

There he saw them making use of the bones of his father, beating them together to keep time while they were repeating their incantations, known only to themselves.

Rata listened attentively until he had learned this incantation by heart.

When he was quite sure that he knew it, he rushed in suddenly upon the priests and killed them and secured his father's bones, and fled to his canoe and, with his warriors, set out for home.

It was not until the morning that the tribe discovered what had been done and who had done it.

Without delay they raised an army and pursued. This army consisted of a thousand fierce warriors.

In the battle which ensued Rata was worsted and sixty of his followers were slain. 
At this moment Rata remembered the powerful incantation he had learned of the priests. He repeated it, and immediately his dead soldiers were restored to life. Then they returned to the fight, fiercer than before, and their enemies were slain. The whole thousand were killed and so Rata was counted in those days as a mighty warrior.

Rata's task of avenging his father being now ended, his tribe drew their great canoe up on the shore and thatched it over to protect it from the sun.

\section{The Legend of Whakatau.}

Whakatau was a grandson of Rata. He was brought into existence in a very strange manner.

His mother, if such she could be called, was one day walking along the seashore when she took off her apron, and rolling it up, threw it into the sea. A god seized it and shaped it, and breathed upon it, and it became a living being, and its ancestors taught him magic and all sorts of curious things. When he was little, his favorite amusement was flying kites.

What was most strange to mortal men was that while they could see kites flying about, they could see no one attending them, for Whakatau was running about on the 


\section{MAORIS OF NEW ZEALAND}

bottom of the sea, holding the end of the string in his hand.

One day he stole up out of the water by degrees till his whole body was plainly visible on the shore.

All the people ran to seize him, but he slipped back into the water and went on flying his kites as before.

The people who saw him were surprised at the strange sight, and they determined to seize him, if possible. So they sat on the shore and watched for him.

When he came up out of the water and stepped on shore again they all ran at full speed to catch him. When he saw them coming he cried out, "You had better go and bring Apakura here; she is the only one who can catch me and hold me fast." They ran to fetch Apakura. When she saw him she said, "Here I am: I am Apakura." Then he stopped running and she caught him, and asked him, "Whom do you belong to?"

He said, "I am your child! You one day threw your apron into the sea, and a god, my ancestor, seized it and from it made me, and I grew up, and they called me Whakatau."

Then he left the water and resided on the land, but his principal amusement, as long as he was a lad, was flying kites. 


\section{MAORIS OF NEW ZEALAND}

But he understood magic well, and nothing was hid from him, and when he grew up to be a man he became a renowned hero.

The following song was often sung in honor of one of their great warriors:

I thought, O Kana! if

I kept the secret still

Untold, unknown and hid,

'Twas dread and fear

Of the still awful doom

Of song and war

That ruled thy every act.

But thou, O Wera,

Hast the red and

Sacred plume, that binds,

Commands, and keeps

In power, and saves

From death thy

Warrior host.

Here is a very ancient lament sung in chorus by the whole tribe over their illustrious dead:

The small stars now

Westward troop in majesty.

The satellites of Mars

Go on in drowsy mood

The path they ever went,

But what may it avail?

Since he, Wari-a-hau,

Rushed reckless to the

Battle front; nor heeded 
That the great, the people's, Power, the guardian and Protector of our hosts Had succumbed to death.

No aid had he to grapple With the unrelenting god Of war. Nor were there then Bright rays of light Seen on the peak of The hill Wai-tawa, where All the mighty men

Lie with Rangi-te-amo There. But seek our guardian Power and rouse it At once to act anew Before our great canoe is Overturned and all is lost.

I'll deck me with the plume Of the white crane as the Gentle breeze from off the sea Wafits to our shore the totara. of prized young chiefs.

Oh, gently blow, ye breezes of the land and rouse To deeds of daring all The active souls of men. I dreamt, and in my dreams, I felt the chill of snow Grate through my frame, Which trembled with the chill. 
As in the night's ill omen, Those Tama-te-a nights of Dread, the signs of which Are seen high up above and In the midnight clouds.

0, my beloved! couldst Thou once again arise And in the day-dawn speak, Thou wouldst the incantation Chant of A-wa-tea-aroa, And tell the power by Which thine ancestors learned The path to come across The ocean road to This our far-off home.

These cannibal people were not only capable poets, as I have pretty fully shown, but they were also a musical people, vocal and instrumental. Their instruments were mostly trumpets, flutes and whistles. They had a few that were not wind instruments, and they were continually trying to invent others. Their attempts in this direction were like what the ancient Greek used to relate of Apollo himself, in the construction of his first lyre or harp, employing a cast-away shell with a few strings stretched across it.

Their trumpets were made of wood or shell. Those of shell were usually made by using the Triton or conch shell. Its apex was neatly cut off, and a mouthpiece of hard wood, 


\section{MAORIS OF NEW ZEALAND}

suitably hollowed and carved, was ingeniously put in and very firmly fixed.

The old Maoris seem to have had a curious plan for increasing or altering the power of sound of their conchshell instrument. A thin piece of dark, hard wood of a broadly elliptic form, and measuring about three by five inches, was most dexterously fitted in to fill up a hole in the upper part of the body or large whorl of the shell. This piece of wood was also carved and ribbed or scraped to resemble and closely match the transverse ridges of the shell.

There was only one kind of wood of sufficiently sonorous quality to suit their taste for this purpose. Of this wood also they made their best loud-sounding drums and gongs. From this same wood they dressed down and polished sticks about three feet long and of the thickness of small walkingsticks. Two persons, standing about four feet apart, each holding one of these prepared rods, would throw them toward each other with such dexterity as to make them strike each other at just such distances from the ends as that they might produce just the sound necessary to suit the note required of the song they were singing.

Their wooden trumpets were also very curious and 


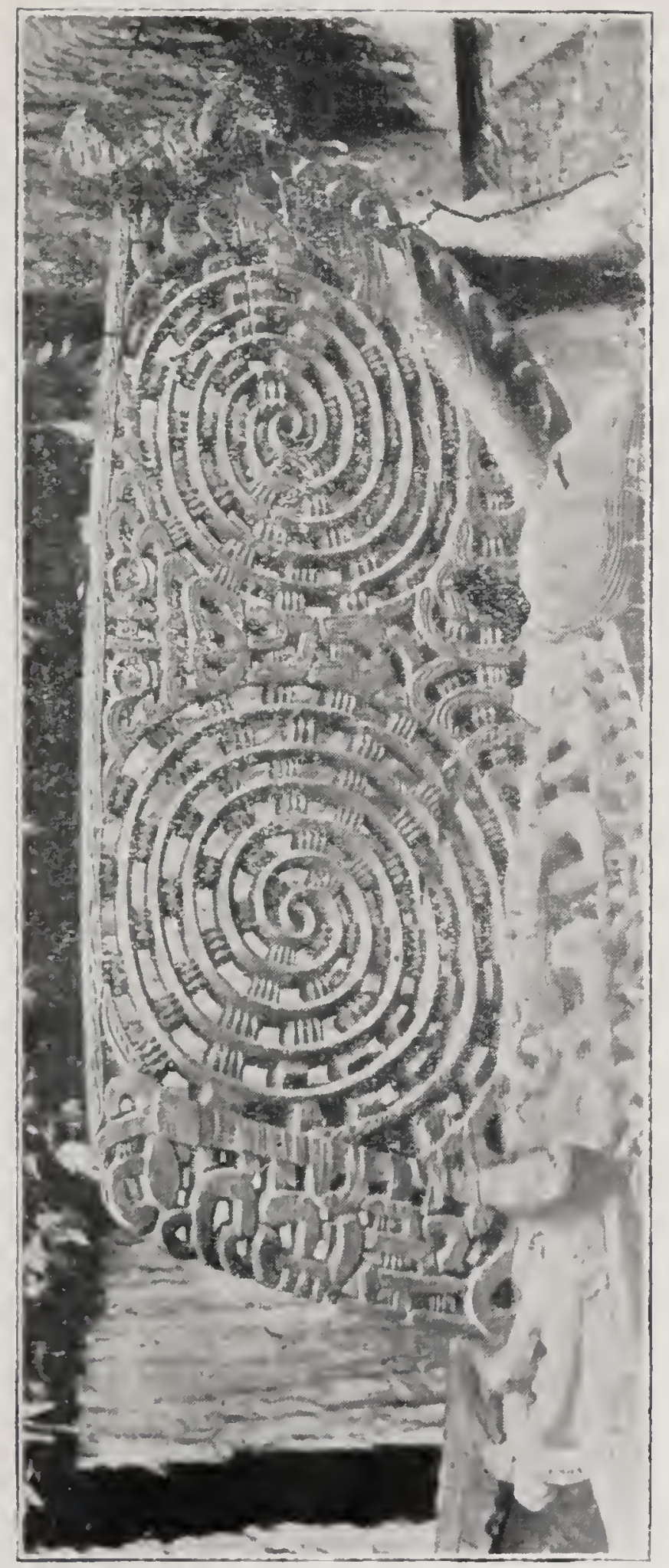

MAORI WOOI) CARVING 



\section{MAORIS OF NEW ZEALAND}

ingenious. They were made of pieces of hard wood, scraped and hollowed and jointed, and very compactly put together. The work was so well done that it was almost impossible to discover the joinings.

Some of the long trumpets had a large hole in the middle of the instrument from whence the sound issued, and which was there modified by the hand.

Others of their trumpets, about four feet in length, had a central piece, or diaphragm, set back twelve or fourteen inches from its mouth. The sound of this instrument was emitted from the large aperture at the big dilated end. By the different sounds of these instruments the several chiefs in travelling were known.

These loud-sounding trumpets were often used as speaking trumpets when giving words of command or other important words to persons at a distance.

The flute was made of wood or of bone. Those of the latter were of human bone. They were generally six or eight inches long and open at both ends. They had four holes, three on one side and one on the other.

The wooden ones were ornamented with a great amount of carving and inlaying, each being an example of skill, industry and patience. 


\section{MAORIS OF NEW ZEALAND}

On these flutes the old Maoris were able to play simple Maori tunes and airs.

The whistles were made of hard wood, scraped, polished, and profusely carved, and inlaid with mother-of-pearl. They were worn by the chiefs, usually hung to their necks. Ability such as many of them manifested could only have been attained through long and persevering practice, indicative of both a good musical ear and love for music.

It was surprising to hear these people from most patient perseverance extract even only a short series of pleasing notes from such instruments.

Ever since the advent of the white man, the Maoris have taken a great interest in jews-harps.

Sometimes they will try a score or more before they can find one soft enough in tone to suit their fancy. They will spend hours and invent all sorts of plans to alter the tone where it is harsh.

They will, for this purpose, fix about the tongue a small bit of sealing-wax or gum. One writer says, "I have known a Maori to beg for an old dessert knife worn out to the thin remnant of a blade that he might make with it a small instrument resembling a jews-harp, its sound being so much sweeter than any he could buy." 
Much of their carving, especially on the prows of their canoes and on the fronts of their dwellings, was most exquisitely artistic as the reader will see by turning to the illustrations given.

Their tattooing was always apparently a thorough work of art. No one was considered really handsome without it.

Well-tattooed heads were mostly always preserved and kept in the home so that the deceased relative might still be counted one of the family.

When white men came in touch with these people, finding that a well-tattooed head could be sold for a good price to the museums and curio hunters in England, a trade for heads sprang up which was very discreditable to the more enlightened race.

The first head made an article of commerce was taken to Sydney, New South Wales, in 1811.

A sailor who had been fishing for some months for seals, stole it from a native house.

As soon as the theft was discovered, there was great excitement among the people.

Fortunately for him and his companions the wind was blowing off shore, and weighing anchor they quickly got away. He realized a good price for the head, but it cost him his life when he returned to New Zealand. 


\section{MAORIS OF NEW ZEALAND}

In England a well-preserved head with very artistic tattooing would bring almost any price demanded.

To such depth of wickedness was the trade at length carried that thousands of slaves were purposely killed that their heads might be sold.

It became unsafe for anyone to be handsomely tattooed unless he was a chief.

An English captain having his vessel loaded with Kauri gum or flax would be offered a head by the chief whose men were carrying cargo aboard.

The captain might refuse because it was not as good a specimen as he wanted. He would point to one of the men whose tattooing he admired and say that if he could get one like that he would give a good price for it.

When he would return a year later with his ship for another cargo, that poor fellow's head would be ready for him. It very often happened that a powerful chief had his slaves all handsomely tattooed that he might kill them and sell their heads for a big price.

One slave who had been tattooed at much expense and weeks of time was dishonest enough to run away with his own head, though the chief might have maintained in an old Maori court that it wasn't his own head.

All we can say is that at least it was a "capital" offence. 


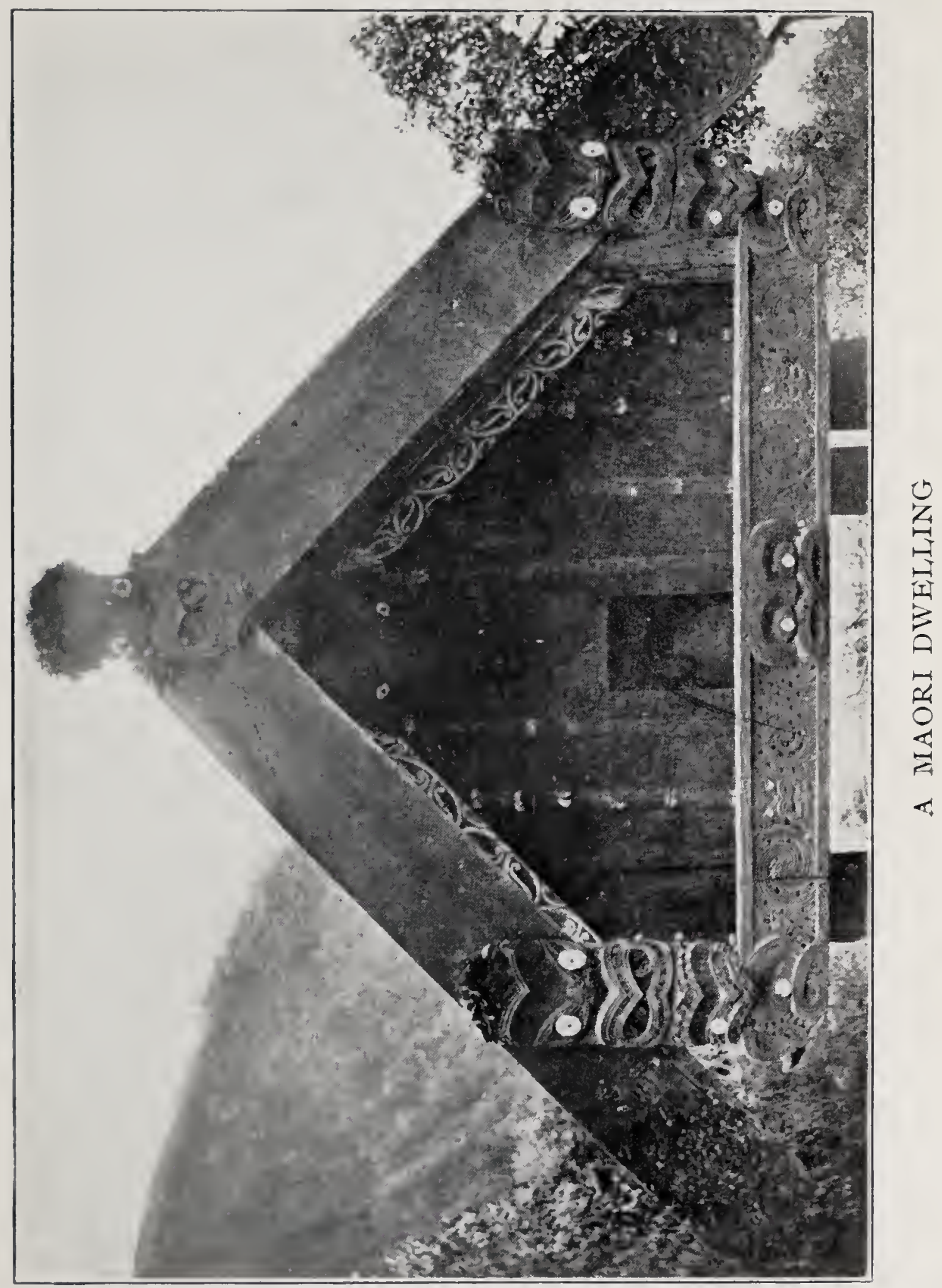





\section{MAORIS OF NEW ZEALAND}

Head for head, all that a man hath will he give for his head. This poor fellow had nothing but "leg bail," so he gave that.

In 1831 a captain of a schooner purchased fifteen heads. When a company of natives came aboard, the captain, being under the influence of liquor, brought the sack and emptied them on the deck before his visitors. They were horrified to see among them the heads of some of their own relatives. He succeeded by a favorable wind in getting away, but he was fired on by the natives when he returned later. His act resulted in the total prohibition of the traffic.

Governor Darling, of New South Wales, issued a proclamation which put a stop forever to this iniquitous traffic.

One of the oldest warriors now living says that through their continued fighting the Taranaki district was left without any adult male native.

Some time after that, all began to feel tired of war, and from both sides warriors from two large warlike tribes met and agreed there should be no more war between them. A gun was buried as a sign that they would fight no more. "Then," says the old warrior, "the gospel came. Since that I and all my people" (of that tribe) "have all accepted the Word of God. When I heard of the rising of some of the people for war, I took the Word of God to the Waikato 


\section{MAORIS OF NEW ZEALAND}

party, and also to their opponents. Eighty of us went. We spoke to the Waikato people and they agreed that there should be no more war. Then they all began to believe in God. When we came again to Waikato, Christianity had greatly spread."

As I have given an extract of a portion of a native song in their own tongue, it may please the reader to see the Lord's Prayer in Maori:

Te inoi a te Ariki $\mathrm{E}$ to matou matua $\mathrm{i}$ te rangi kai tapu tou Ingoa. Kai mai tou Ranga tiratanga.

Kia meatia tou epaiia ki runga Kite whenua. Kia rite ana kito te rangi. Homai kia matou aranei he taro ma matou mo tenei ra.

Murua O matou hara me matou hoki a muru nei i ote hungae hara ana kia a matou. Ana hoke matou e kaiwea kia whakawaia engara whakarangia matou te kino.

Mau hoki te rangatiratanga, te kaha me te kororia.

Ake, Ake, Ake, Amine.

Te inoi a te Ariki.

The prayer of the Lord.

$\mathrm{E}$ to matou matua i te rangi,

$O$ our Father in the heaven

kai tapu tou Ingoa, kal mal tou

let be sacred thy name, let come thy

Ranga tiratanga

Kingdom (chieftainship),

kia metia tou epaiai ki runga

let be done thy will on to

kite whenua. Kia rite ana kito 


\section{MAORIS OF NEW ZEALAND}

the earth, let it accord with

te rangi.

that in heaven.

Homai kia matou aranai he taro

Give to us now some bread

ma matou mo tenei ra.

for us for this day.

Murua O matou hara me matou

Blot out our sins as we

hoki e muru nei i ote

also blot out those of the

hungae hara, ana kai a matou,

people who sin against us.

Ana hoke ma tou e kaiwea

Not also us take

kia whakawaia, engri whakarangia

to be tempted, but deliver

matou te kino,

us from the evil.

Nau hoki te rangatiratanga

Thine also the kingdom,

te kaha me to kororia, the power and the glory,

Ake, ake, ake, Amine.

Ever, ever, ever, Amen.

If these pagan people saw some things which the white people had brought to them that were good, they saw also that some of the white man's customs were bad.

They saw from the very beginning the evil effects of intoxicating liquors. 


\section{MAORIS OF NEW ZEALAND}

They resolved that, at a very early period in their more civilized condition, this evil should not continue among them.

Their first prohibitory law dates as far back as 1835 .

Moetara, a native chief, was at the head of this movement.

About 500 Maoris were present when resolutions were passed, through the assistance of a few English-speaking residents, that the sale of intoxicants should be abolished.

It was decided that there should be a fine of $£ 25$ each put upon vendor and purchaser.

A deputation was sent to a vessel loading for Australia, and the rum cask in her hold was demanded.

So much harm had been done that the people were determined. When the captain saw that the demand was backed up by 500 natives, he hoisted the cask on deck, the bung was drawn, and the Maoris turned the grog into the sea.

The poor captain said, "Things have come to a pretty pass when we have to go to sea without our supply of grog."

No opposition came from the blacks. They were all against the use of that which produced such effects upon men. 


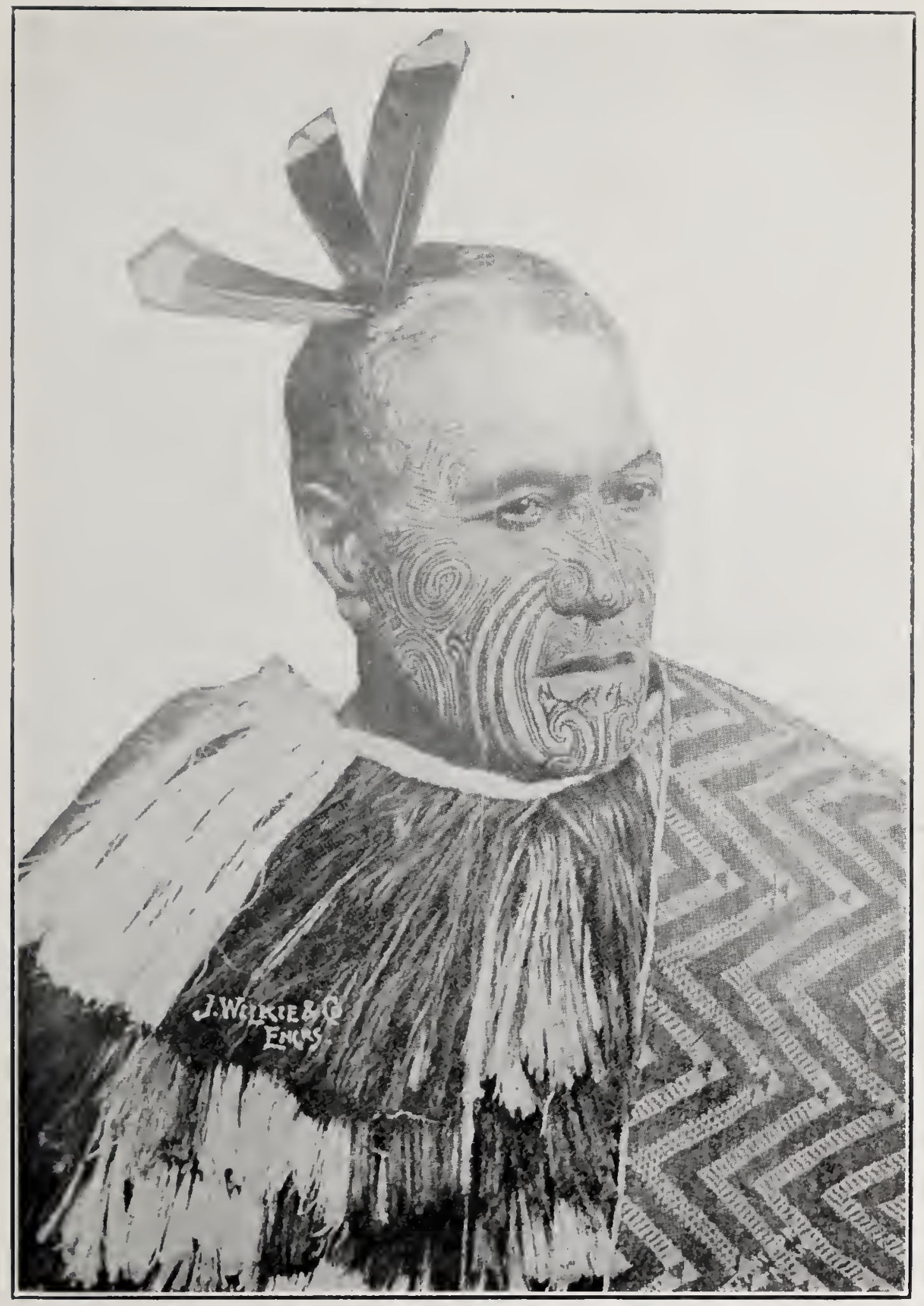

MIOFTARA 

Their very strongest objection to the introduction of Christianity was on this ground.

They saw among those who were taking possession of their lands, and among the sailors, men-who claimed to have a better religion and a better civilization than their own-behaving worse than demons and besotting themselves worse than brutes, and some of them could not disassociate their boasted religion and civilization from the doings of the drinkers of rum.

Opposition to the prohibitory movement came from white men.

A few of these, knowing that the missionary had encouraged the movement, gathered around the mission house and drank their rum and flourished their rum bottles.

One of these in their drunken row received a blow on the head from one of his drunken companions, which caused his death a few hours later.

He was a general dealer, and a man of mark among his fellows.

He sent for the missionary and expressed his sorrow for his opposition to him and to the chiefs.

He ordered all his rum casks up from the cellar and had them emptied upon the ground before the eyes of his wicked associates. 
From that day until now prohibition has prevailed in the whole of the "King Country," that is, that part of New Zealand exclusively occupied by the Maori people.

Thanks to the noble example set by these native people, New Zealand makes more persistent progress towards the total annihilation of this infamous traffic than any other of the British Colonies.

The self-sacrificing zeal of the Christian people of that beautiful colony is worthy of all praise.

That white-skinned civilized men should cling to this traffic with all its hellish nature and history is one of those mysteries most difficult of solution.

The beverage use of an intoxicant is contrary to the laws of nature and to the declared will and mind of God.

Its continued hold upon humanity is one of the strongest evidences of the existence and activity of Satan with legions of demons under his control whose chiefest business is to destroy men; and never in all the history of invention for human ruin has any other thing been devised of greater potency for the accomplishment of its purpose.

I have given in preceding pages illustrations of Maori poetry. I think the reader will be glad to have here a poem by a New Zealander, though not a native.

Perhaps the reader will have more sympathy with these 
lines if I inform him that the gifted author of these very forcible and touching sentiments was a sufferer from the drink habit.

Even after composing this poem he was still a slave to rum. I hope, if he still lives, he has become free, for oh, what a slavery it is!

\section{THE VILEST FIEND OF ALL.}

False demon, take thy fiendish shape;

Thy name is demon and not wine.

Durst thou cling to the purple grape?

Durst thou take shelter 'neath the vine?

Nay, cling unto thy patron-Death-

And hide thee 'neath his blackest pall.

Throughout creation's length and breath

Thou art the vilest fiend of all.

What are thy crimes? Go ask the grave

That yawning waits the lifeless clod,

Thy murdered serf, thy pcisoned slave:

A type once of the living God.

The shrieks within the maniac's cell,

The chain-clanks round the prison wall,

The wails and groans of millions tell

Thou art the vilest fiend of all.

What are thy crimes? Yon soulless thing

Was once God's image, pure and fair.

Yea, fiend, as witnesses, I bring

Lust, hatred, murder and despair 


\section{MAORIS OF NEW ZEALAND}

To prove thy guilt. The fiercest flame That burns below where sinners fall Is fed by thee. Remorse and shame Proclaim thee vilest fiend of all.

What are thy crimes? Thy counsel's plea Is this: Thou'rt good and we should prize Heaven's gifts; but I do view in thee

A cruel devil in disguise;

Before thee, peace and comfort fly, Replaced by senseless feud and brawl; Near thee, truth, love and honor die:

Thou art the vilest fiend of all. 


